\title{
Article \\ Interaction between ZnO Nanoparticles and Albumin and Its Effect on Cytotoxicity, Cellular Uptake, Intestinal Transport, Toxicokinetics, and Acute Oral Toxicity
}

\author{
Eun-Been Jung, Jin Yu (D) and Soo-Jin Choi * (D) \\ Division of Applied Food System, Major of Food Science \& Technology, Seoul Women's University, \\ Seoul 01797, Korea; ebe2@swu.ac.kr (E.-B.J.); ky5031@swu.ac.kr (J.Y.) \\ * Correspondence: sjchoi@swu.ac.kr; Tel.: +82-2-970-5634
}

\section{check for} updates

Citation: Jung, E.-B.; Yu, J.; Choi, S.-J. Interaction between $\mathrm{ZnO}$ Nanoparticles and Albumin and Its Effect on Cytotoxicity, Cellular Uptake, Intestinal Transport, Toxicokinetics, and Acute Oral Toxicity. Nanomaterials 2021, 11, 2922. https://doi.org/10.3390/nano1111 2922

Academic Editors: Fabien Grasset and Olivier Joubert

Received: 29 September 2021

Accepted: 28 October 2021

Published: 31 October 2021

Publisher's Note: MDPI stays neutral with regard to jurisdictional claims in published maps and institutional affiliations.

Copyright: (c) 2021 by the authors. Licensee MDPI, Basel, Switzerland. This article is an open access article distributed under the terms and conditions of the Creative Commons Attribution (CC BY) license (https:// creativecommons.org/licenses/by/ $4.0 /)$.

\begin{abstract}
Zinc oxide ( $\mathrm{ZnO})$ nanoparticles (NPs) are used as zinc supplements due to the nutritional value of $\mathrm{Zn}$. The toxicity of $\mathrm{ZnO}$ NPs in the food industry is required to be elucidated because they have large surface area and high reactivity compared with bulk-sized materials and have potentials to interact with food matrices, which may lead to different biological responses. In this study, interactions between ZnO NPs and food proteins (albumin, casein, and zein) were evaluated by measuring changes in physicochemical property, fluorescence quenching ratios, and structural protein stability compared with $\mathrm{ZnO}$ interaction with glucose, the most interacted saccharide in our previous report. The interaction effects on cytotoxicity, cellular uptake, intestinal transport, toxicokinetics, and acute oral toxicity were also investigated. The results demonstrate that interaction between $\mathrm{ZnO}$ and albumin reduced hydrodynamic diameters, but increased cytotoxicity, cellular uptake, and intestinal transport in a similar manner to $\mathrm{ZnO}$ interaction with glucose, without affecting primary structural protein stability and toxicokinetic behaviors. Hematological, serum biochemical, and histopathological analysis reveal no toxicological findings after orally administered ZnO NPs interacted with albumin or glucose in rats for 14 consecutive days, suggesting their low oral toxicity. In conclusion, the interactions between $\mathrm{ZnO}$ NPs and food proteins modulate in vitro biological responses, but do not affect in vivo acute oral toxicity. Further study is required to ascertain the interaction effects on chronic oral toxicity.
\end{abstract}

Keywords: zinc oxide; food protein; interactions; cytotoxicity; cellular uptake; intestinal transport; toxicokinetics; acute oral toxicity

\section{Introduction}

Zinc oxide $(\mathrm{ZnO})$ has multifunctionality due to its semi-conductor, optical, biological, and antibacterial properties [1]. $\mathrm{ZnO}$ is also applied to various commercial foods as a $\mathrm{Zn}$ supplement or agricultural fertilizer due to nutrient value and diverse biological functions of $\mathrm{Zn} \mathrm{[2-5].} \mathrm{ZnO}$ is an essential mineral for the body and a generally recognized as safe (GRAS) material. However, high level of Zn causes nausea, vomiting, stomach pain, diarrhea, flu-like symptoms, and other nutritional deficiency [6-8]. Nanotechnology development has led to the production of $\mathrm{ZnO}$ nanoparticles (NPs) in the size range of 1-100 nm, which can change physicochemical properties and biological responses of $\mathrm{ZnO}$ compared with those of bulk-sized materials. Moreover, food additive ZnO NPs are added directly to foods consisting of proteins, carbohydrates, minerals, and other components. Hence, interactions between ZnO NPs and food matrices can easily occur, which may lead to different physicochemical, biological, and toxicological effects compared with those of pristine ZnO NPs [9-11].

Remarkably reduced hydrodynamic diameters of silicon dioxide $\left(\mathrm{SiO}_{2}\right)$ and titanium dioxide $\left(\mathrm{TiO}_{2}\right)$ NPs and their high oral absorption in rats were found when $\mathrm{SiO}_{2}$ and $\mathrm{TiO}_{2}$ NPs were dispersed in glucose and serum albumin, respectively, compared with 
those of NPs in distilled water (DW) $[12,13]$. These results suggest that the interactions between NPs and glucose or serum albumin could reduce the hydrodynamic diameters of NPs by increasing dispersion stability, consequently contributing towards enhancing their in vivo oral absorption. The role of NP-protein interaction, protein corona, in the immune system was also emphasized [14-17]. The lipid and protein corona of food additive $\mathrm{TiO}_{2} \mathrm{NP}$ in an in vitro simulated gastrointestinal digestion fluid was demonstrated, which reduced oxidative stress and cytotoxicity in cell lines [18]. Interactions between $\mathrm{ZnO}$ NPs and saccharide matrices, such as fructose, glucose, sugar mixture, and acacia honey containing high levels of saccharides, were quantitatively determined in our previous reports [9]. Among them, glucose was found to significantly enhance cellular uptake, intestinal transport, and in vivo oral absorption of $\mathrm{ZnO}$ NPs [9]. On the other hand, a contradictory result was reported, showing that a high protein-containing complex food (skim milk) or its main components, casein and lactose, had no effect on cytotoxicity, cellular uptake, or intestinal transport of ZnO NPs [10]. Therefore, the effects of interactions between $\mathrm{ZnO}$ NPs and food matrices on in vitro and in vivo biological responses are required to be investigated more extensively to predict and understand potential toxicity of food-additive NPs.

We hypothesized that ZnO NPs can interact with food proteins, which may modulate in vitro and in vivo biological responses. In this study, interactions between ZnO NPs and food proteins, such as albumin from chicken egg white, casein from bovine milk, and zein from corn, were evaluated in terms of physicochemical properties, protein fluorescence quenching, structural protein stability, cytotoxicity, cellular uptake, intestinal transport, and in vivo oral absorption. Comparative study with glucose, the most interacted saccharide with ZnO NPs in our previous report [9], was also carried out. Finally, in vivo oral toxicity study was performed after oral administration of ZnO NPs interacted with proteins or glucose in rats for 14 consecutive days to answer the question whether the interactions affect acute oral toxicity of ZnO NPs.

\section{Materials and Methods}

\subsection{Materials and NP Preparation}

ZnO NPs (product number 544906, particle size $<100 \mathrm{~nm}$, specific surface area 10-25 $\mathrm{m}^{2} / \mathrm{g}$, purity $>95 \%$ ), albumin from chicken egg white, casein salt from bovine milk, zein, D- (+)-glucose, ethylenediaminetetraacetic acid disodium salt dihydrate (EDTA), pepsin from porcine gastric mucosa, and $\beta$-mercaptoethanol were purchased from Sigma-Aldrich Co. Ltd. (St. Louis, MO, USA). Sodium dodecyl sulfate (SDS) and Tris were provided by Duchefa Biochemie (Haarlem, The Netherlands). Acrylamide-bis solution (29:1) and 0.1\% bromophenol blue were supplied from Bio-Rad Laboratories Inc. (Hercules, CA, USA), and Daejung (Siheung, Gyeonggi-do, Korea), respectively. Ammonium persulfate, ethyl alcohol, nitric acid $\left(\mathrm{HNO}_{3}\right)$, hydrogen peroxide $\left(\mathrm{H}_{2} \mathrm{O}_{2}\right)$, hydrogen chloride $(\mathrm{HCl})$, and glycerol were supplied by Samchun Pure Chemical Co., Ltd. (Pyeongtaek, Gyeonggi-do, Korea). Minimum essential medium (MEM), Dulbecco's modified Eagle's medium (DMEM), Roswell Park Memorial Institute (RPMI) 1640, inactivated fetal bovine serum (FBS), penicillin, streptomycin, Dulbecco's phosphate-buffered saline (DPBS), and phosphate-buffered saline (PBS) were purchased from Welgene Inc. (Gyeongsan, Gyeongsangbuk-do, Korea). Watersoluble tetrazolium salt (WST-1) and $2^{\prime}, 7^{\prime}$-dichlorofluorescein diacetate $\left(\mathrm{H}_{2} \mathrm{DCFDA}\right)$ were provided by Roche (Mannheim, Germany) and Molecular Probes Inc. (Eugene, OR, USA), respectively. A CytoTox 96 Nonradioactive Cytotoxicity Assay kit was obtained from Promega (Madison, WI, USA). Matrigel from Corning Inc. (Corning, NY, USA) and Transwell polycarbonate inserts from SPL Life Science Co., Ltd. (Pocheon, Gyeonggi-do, Korea) were used.

Stock suspension of ZnO NPs ( $5 \mathrm{mg} / \mathrm{mL}$ ) was prepared in DW, MEM, casein ( $1 \mathrm{mg} / \mathrm{mL}$ ), albumin $(1 \mathrm{mg} / \mathrm{mL})$, zein $(1 \mathrm{mg} / \mathrm{mL})$, or glucose $(1 \mathrm{mg} / \mathrm{mL})$ solutions by stirring for $30 \mathrm{~min}$, followed by bath sonication (160 Watts, Bransonic 5800, Branson Ultrasonics, Danbury, CT, 
USA) for 5 min prior to all experiments. Zein, a water insoluble protein, was dissolved in $94.5 \%$ ethanol at $10 \mathrm{mg} / \mathrm{mL}$ and diluted to $1 \mathrm{mg} / \mathrm{mL}$ with DW or MEM before experiments.

\subsection{Characterization}

The constituent particle size and shape of ZnO NPs were determined by field emissionscanning electron microscopy (FE-SEM; JSM-7100F, JEOL, Tokyo, Japan). Particle size distribution was measured by randomly selecting more than 100 particles from the SEM images. Hydrodynamic diameters and zeta potentials of ZnO NPs prepared in DW, MEM, and each food matrix solution were measured via dynamic light scattering (DLS) and electrophoretic light scattering, respectively, using a Zetasizer Nano System (Zetasizer Nano ZS, Malvern Instruments, Worcestershire, UK) after dilution with DW and MEM, respectively.

\subsection{Dissolution Properties of $\mathrm{ZnO} N \mathrm{NS}_{\mathrm{s}}$}

The effect of the interactions between ZnO NPs and food proteins on the solubility of $\mathrm{ZnO}$ NPs was investigated by dispersing $\mathrm{ZnO} N P s(5 \mathrm{mg} / \mathrm{mL})$ interacted with food proteins in DW, MEM, or artificial lysosomal fluid (ALF, Table S1) with shaking at $37^{\circ} \mathrm{C}$ [19]. After $0.5,1,6$, and $24 \mathrm{~h}$, the supernatants were collected by ultracentrifugation $(16,000 \times g)$ for $15 \mathrm{~min}$. Solubility of ZnO NPs in in vitro simulated digestion models (Table S2) was also evaluated by dispersing $\mathrm{ZnO} N \mathrm{Ns}(5 \mathrm{mg} / \mathrm{mL})$ interacted with food proteins in simulated saliva, gastric fluid, and intestinal fluids for $5 \mathrm{~min}, 2 \mathrm{~h}$, and $2 \mathrm{~h}$, respectively, on a headover-head rotator at $37^{\circ} \mathrm{C}$ [20]. For solubility in three consecutive digestion fluids, $\mathrm{ZnO}$ NPs $(5 \mathrm{mg} / \mathrm{mL})$ were dispersed in $6 \mathrm{~mL}$ of simulated saliva for $5 \mathrm{~min}$ at $37^{\circ} \mathrm{C}$, followed by digestion in $12 \mathrm{~mL}$ of gastric fluid for $2 \mathrm{~h}$ at $37^{\circ} \mathrm{C}$. Finally, the digestion was carried out for a further $2 \mathrm{~h}$ at $37^{\circ} \mathrm{C}$ after addition of $12 \mathrm{~mL}$ of duodenal fluid and $6 \mathrm{~mL}$ of bile fluid to the suspension. After the samples were centrifuged at $16,000 \times g$ for $15 \mathrm{~min}$, quantitative analysis of the dissolved $\mathrm{Zn}$ from $\mathrm{ZnO}$ in the supernatants was carried out using inductively coupled plasma-atomic emission spectroscopy (ICP-AES; JY2000 Ultrace, HORIBA Jobin Yvon, Longjumeau, France), as described in "2.4. ICP-AES Analysis". ALF and digestion fluids were prepared on the day of the experiment at $37^{\circ} \mathrm{C}$.

\subsection{ICP-AES Analysis}

All samples were digested with $10 \mathrm{~mL}$ of ultrapure $\mathrm{HNO}_{3}$ at $\sim 160{ }^{\circ} \mathrm{C}$, and $1 \mathrm{~mL}$ of $\mathrm{H}_{2} \mathrm{O}_{2}$ solution was added and heated until the samples were colorless and clear. After digestion, the samples were diluted with distilled and deionized water (DDW), and total Zn concentrations were determined by ICP-AES (JY2000 Ultrace, HORIBA Jobin Yvon, Longjumeau, France).

\subsection{Fluorescence Quenching of Food Proteins by ZnO NPs}

Interactions between $\mathrm{ZnO}$ NPs and food proteins were investigated by measuring fluorescence quenching ratios. $\mathrm{ZnONPs}(0.5 \mathrm{mg} / \mathrm{mL})$ were suspended in casein $(1 \mathrm{mg} / \mathrm{mL})$, albumin $(1 \mathrm{mg} / \mathrm{mL})$, or zein $(1 \mathrm{mg} / \mathrm{mL})$ and incubated with gentle shaking at $25^{\circ} \mathrm{C}$. After incubation for $0.02,0.5,1,6$, and $24 \mathrm{~h}$, the suspensions were transferred to quartz cuvettes and protein fluorescence quenching was analyzed using a luminescence spectrometer (SpectraMax M3, Molecular Devices, Sunnyvale, CA, USA). The excitation wavelength was set at $280 \mathrm{~nm}$ and fluorescence emission was scanned at wavelengths from 300 to $420 \mathrm{~nm}$. Fluorescence quenching ratios were calculated according to the equation: $\left(\mathrm{I}_{0}-\mathrm{I}\right) / \mathrm{I}_{0}$, where $\mathrm{I}_{0}$ and I are the fluorescence intensity of proteins in the absence and presence of $\mathrm{ZnO}$ NPs, respectively.

\subsection{SDS-Polyacrylamide Gel Electrophoresis (PAGE) Analysis}

Changes in the primary structure of food proteins by interaction with $\mathrm{ZnO}$ NPs were analyzed by SDS-PAGE. Casein, albumin, or zein $(1 \mathrm{mg} / \mathrm{mL})$ were incubated with $\mathrm{ZnO}$ NPs $(0.5 \mathrm{mg} / \mathrm{mL})$ by gentle shaking at $25^{\circ} \mathrm{C}$ for $0.02,0.5,1,6$, and $24 \mathrm{~h}$. 
Effect of the interactions on the digestion of food proteins was evaluated by pepsin treatment. Pepsin at final concentration of 1990 units/mL was added to ZnO NPs-protein suspensions and their $\mathrm{pH}$ were adjusted to 1.5 with $1 \mathrm{~N} \mathrm{HCl}$. After incubation for $1 \mathrm{~h}$ at $37^{\circ} \mathrm{C}$ with gentle shaking, the samples were concentrated using a nitrogen evaporator (MG-3100, Eyela, Tokyo, Japan). All protein samples were re-suspended in DW (1 mL) and concentration of proteins were determined using Bradford reagent (Bio-Rad, Hercules, CA, USA).

Protein samples were diluted in sample buffer, $50 \mathrm{mM}$ Tris- $\mathrm{HCl}(\mathrm{pH}$ 6.8) containing $4 \%$ SDS, $0.1 \%$ bromophenol blue, $10 \%$ glycerol, and $0.5 \% \beta$-mercaptoethanol, and heated at $95{ }^{\circ} \mathrm{C}$ for $5 \mathrm{~min}$. After cooling to room temperature, samples were loaded onto $14 \%$ SDSpolyacrylamide gels and electrophoresis was performed with a power supply (MP-3AP, Major science, Saratoga, CA, USA) under a voltage of $150 \mathrm{~V}$ for $2 \mathrm{~h}$.

\subsection{Cytotoxicity}

\subsubsection{Cell Culture}

Human intestinal epithelial Caco-2 cells and human Burkitt's lymphoma Raji B cells were purchased from the Korean Cell Line Bank (Seoul, Korea). The cells were cultured in MEM and RPMI, respectively, supplemented with $10 \%$ FBS, 100 units $/ \mathrm{mL}$ of penicillin, and $100 \mu \mathrm{g} / \mathrm{mL}$ of streptomycin in a $5 \% \mathrm{CO}_{2}$ incubator at $37^{\circ} \mathrm{C}$.

\subsubsection{Cell Proliferation}

The interaction effect on cell proliferation was measured with WST-1 (Roche). Cells $\left(1 \times 10^{4}\right.$ cells $\left./ 100 \mu \mathrm{L}\right)$ were treated with ZnO NPs suspended in DW, MEM, or each food matrix solution. All food matrices $(1 \mathrm{mg} / \mathrm{mL})$ for cell experiments were prepared in MEM by stirring for $30 \mathrm{~min}$. After incubation for $24 \mathrm{~h}, 10 \mu \mathrm{L}$ of WST-1 solution was added to each well and further reacted for $4 \mathrm{~h}$. The absorbance was measured at $440 \mathrm{~nm}$ versus $650 \mathrm{~nm}$ using a microplate reader (SpectraMax M3, Molecular Devices, Sunnyvale, CA, USA).

\subsubsection{Lactate Dehydrogenase Leakage (LDH) Assay}

The released levels of LDH were measured with the CytoTox 96 Non-Radioactive Cytotoxicity assay (Promega, Madison, WI, USA). Cells $\left(1 \times 10^{4}\right.$ cells $\left./ 1 \mathrm{~mL}\right)$ were treated with $\mathrm{ZnO}$ NPs suspended in DW, MEM, or each food matrix solution. After $24 \mathrm{~h}$, the medium was collected and centrifuged, and $50 \mu \mathrm{L}$ of the supernatants were treated with a substrate solution $(50 \mu \mathrm{L})$ for $30 \mathrm{~min}$ in the dark at room temperature. Finally, $50 \mu \mathrm{L}$ of a stop solution was added and the absorbance was measured at $490 \mathrm{~nm}$ with a microplate reader (SpectraMax M3, Molecular Devices).

\subsubsection{Reactive Oxygen Species (ROS) Generation}

The intracellular levels of ROS were evaluated using a peroxide-sensitive fluorescent probe, $\mathrm{H}_{2}$ DCFDA. Cells $\left(1 \times 10^{4}\right.$ cells $\left./ 100 \mu \mathrm{L}\right)$ were incubated with $\mathrm{ZnO}$ NPs dispersed in DW, MEM, or each food matrix solution. After $24 \mathrm{~h}, 20 \mu \mathrm{M} \mathrm{H}_{2}$ DCFDA was added to each well and further incubated for $30 \mathrm{~min}$ in the dark at $37^{\circ} \mathrm{C}$. Finally, the wells were washed with DPBS and $2^{\prime}, 7^{\prime}$-dichlorofluorescein (DCF) fluorescence was immediately measured by a fluorescence microplate reader (SpectraMax M3, Molecular Devices, Sunnyvale, CA, USA). The excitation and emission wavelengths were set at $485 \mathrm{~nm}$ and $535 \mathrm{~nm}$, respectively.

\subsection{Cellular Uptake}

Cells $\left(1 \times 10^{6}\right.$ cells $\left./ 2 \mathrm{~mL}\right)$ were incubated with $\mathrm{ZnO} N \mathrm{NP}(50 \mu \mathrm{g} / \mathrm{mL})$ prepared in DW, MEM, or each food matrix solution. After $6 \mathrm{~h}$, the cells were washed three-times with DPBS and treated with $5 \mathrm{mM}$ EDTA for $40 \mathrm{~s}$ to detach adsorbed NPs on the membrane surface. After washing with DPBS three-times, the cells were harvested with a scraper, centrifuged, and re-suspended in DDW. Total intracellular Zn levels were analyzed as described in "2.4. ICP-AES Analysis". The cells in the absence of NPs were used as a control. 


\subsection{Intestinal Transport}

A follicle-associated epithelial (FAE) model, mimicking microfold (M) cells, was prepared as previously described $[10,21]$. Transwell polycarbonate inserts were coated with Matrigel matrix prepared in serum-free DMEM for $2 \mathrm{~h}$ and washed with serum-free DMEM. Caco- 2 cells $\left(1 \times 10^{6}\right.$ cells/well $)$ were cultured on apical sides and grown for 14 days. Lymphoma Raji B cells $\left(1 \times 10^{6}\right.$ cells/well $)$ were added to the basolateral sides and the co-cultures were maintained for 5 days until trans epithelial electrical resistance (TEER) values reached $150-200 \Omega \mathrm{cm}^{2}$. The apical medium of co-culture monolayers was replaced with $\mathrm{ZnO}$ NPs ( $50 \mu \mathrm{g} / \mathrm{mL}$ ) prepared in DW, MEM, or each food matrix solution and incubated for $6 \mathrm{~h}$.

Caco-2 monoculture was also used to evaluate the transport of ZnO NPs by the intestinal epithelial tight junction barriers. Caco-2 cells $\left(4.5 \times 10^{5}\right.$ cells $/$ well $)$ were cultured on apical sides for 21 days (TEER $\geq 300 \Omega \mathrm{cm}^{2}$ ). The apical medium of the monolayers was replaced with ZnO NPs (50 $\mathrm{gg} / \mathrm{mL}$ ) prepared in DW, MEM, or each food matrix solution and incubated for $6 \mathrm{~h}$. Finally, the basolateral solutions were collected and analyzed as described in "2.4. ICP-AES Analysis". The FAE and Caco-2 monolayer models in the absence of $\mathrm{ZnO}$ NPs were used as controls.

\subsection{Animals}

Six-week-old female Sprague-Dawley SD rats weighing 170-180 g were purchased form Koateck (Pyeongtaek, Gyeonggi-do, Korea). Rats were housed in laboratory animal cages placed in a ventilated rack maintained at $20 \pm 2{ }^{\circ} \mathrm{C}$ and $60 \pm 10 \%$ relative humidity with a $12 \mathrm{~h} \mathrm{light/dark} \mathrm{cycle.} \mathrm{Water} \mathrm{and} \mathrm{commercial} \mathrm{laboratory} \mathrm{complete} \mathrm{food} \mathrm{for} \mathrm{rats} \mathrm{were}$ given ad libitum. Animals were environmentally acclimated for 7 days before administration. All animal experiments were conducted in accordance with guidelines for the Institutional Animal Care and Use Committee (IACUC) of the Seoul Women's University. Protocols used in this study were approved by the Seoul Women's University IACUC (SWU IACUC-2019A-1).

\subsection{Toxicokinetic Study}

Six female rats per group ( $200 \mathrm{~g})$ were administered a single dose $(100 \mathrm{mg} / \mathrm{kg})$ of $\mathrm{ZnO}$ NPs dispersed in DW, $5 \%$ albumin, or $5 \%$ glucose via oral gavage. Blood samples from the tail veins of the rats were collected at $0,0.25,0.5,1,2,4,6,10$, and $24 \mathrm{~h}$ after administration, and centrifuged at $3000 \times g$ at $4{ }^{\circ} \mathrm{C}$ for $15 \mathrm{~min}$ to obtain the plasma. The total plasma Zn concentrations were analyzed as described in "2.4. ICP-AES Analysis". The following toxicokinetic parameters were assessed using pharmacokinetic modeling program (version 1.03.35, APL, Eden Prairie, MN, USA): maximum concentration $\left(\mathrm{C}_{\max }\right)$, time to maximum concentration $\left(\mathrm{T}_{\max }\right)$, area under the plasma concentration-time curve (AUC), half-time $\left(\mathrm{T}_{1 / 2}\right)$, mean residence time $(\mathrm{MRT})$, and oral clearance $(\mathrm{Cl} / \mathrm{F})$.

\subsection{4-Day Repeated Oral Toxicity Study}

Five female rats per group were administered $\mathrm{ZnO} N P s(100 \mathrm{mg} / \mathrm{mL})$ dispersed in DW, $5 \%$ albumin, or $5 \%$ glucose via oral gavage for 14 consecutive days. An equivalent volume of DW was also administered in rats as a control. Changes in body weight, food intake, and water consumption were recorded daily, and abnormal symptoms and behaviors were observed after oral administration. At the end of the experiment, all animals were euthanized by $\mathrm{CO}_{2}$ and organs including brain, heart, kidney, large intestine, liver, lung, ovary, small intestine, spleen, and stomach were collected. Organo-somatic indices were calculated by the following formula: weight of the organ $(\mathrm{g}) /$ total body weight $(\mathrm{g}) \times$ 100. Blood samples were collected from the posterior vena cava for hematological and serum biochemical analysis as previously described [22]. Hematological, aggregation time, and biochemical analysis were performed by using automatic hemato-analyzer (ADVIA 2120i, Siemens, Tarrytown, NY, USA), coagulometer (ALC 7000, Werfen Medical, IL, USA), and biochemical analyzer (TBA-120FR, Toshiba, Otawara, Japan), respectively. Organs 
including kidneys, liver, lungs, and spleen were fixed with $10 \%$ neutral buffered formalin and stained with hematoxylin and eosin for histopathological examination.

\subsection{Statistical Analysis}

All experimental data were presented as means \pm standard deviations. One-way analysis of variance with Tukey's test in SAS version 9.4 (SAS Institute Inc., Cary, NC, USA) was performed to determine the significances of intergroup differences. Statistical significance was accepted for $p$ values of $<0.05$.

\section{Results and Discussion}

\subsection{Characterization of $\mathrm{ZnO} N P s$ in Food Proteins}

The constituent particle sizes of $Z \mathrm{nO}$ NPs were determined to be $\sim 78 \pm 26 \mathrm{~nm}$ with irregular round or oval shapes by SEM analysis (Figure S1). The hydrodynamic diameters and zeta potentials of ZnO NPs in the presence of food proteins, glucose, or MEM are presented in Figure 1. Glucose was included for comparative study because our previous report demonstrated that ZnO NPs in glucose had higher cellular uptake, intestinal transport, and in vivo oral absorption than those of ZnO NPs in other saccharide matrices [8]. Cell culture medium, such as MEM, was reported to play a role in NP dispersion and ZnO NPs in MEM also exhibited efficient cellular uptake and intestinal transport $[9,23,24]$. The hydrodynamic diameters of ZnO NPs were measured after interaction with food proteins, glucose, or MEM, followed by dilution in DW or MEM. Figure 1A shows that the hydrodynamic diameters of ZnO NPs increased compared with constituent particle sizes (Figure S1), indicating their aggregate fate under aqueous conditions. The role of MEM as an NP dispersant was not remarkable, except ZnO NPs in zein, a highly insoluble protein in water $[25,26]$. Among food proteins, ZnO NPs in albumin showed the smallest hydrodynamic diameters, whereas ZnO NPs were found to be highly aggregated by interaction with casein or zein. It is worth noting that ZnO NPs interacted with glucose had the same hydrodynamic diameters to those of ZnO NPs in albumin when DLS was measured after dispersion in both DW and MEM. These results suggest that the hydrodynamic diameters of $\mathrm{ZnO}$ NPs could be highly affected by interaction with food matrices.

Zeta potential values of $\mathrm{ZnO}$ NPs differed from matrix types when they were measured in DW (Figure 1B). The zeta potentials of $\mathrm{ZnO} N$ Ps in DW were $16.3 \pm 0.8 \mathrm{mV}$ but became negative when $\mathrm{ZnO} N$ ss were interacted with albumin or casein. Indeed, isoelectric points (IEPs) of albumin and casein are 4.9 and 4.6, respectively. Hence, negative charges of albumin and casein at neutral $\mathrm{pH}$ seem to change zeta potential values of $\mathrm{ZnO}$ NPs to negative charges by the interactions. On the other hand, zein with IEP at 6.2 had minor effect on zeta potential of $\mathrm{ZnO} \mathrm{NPs}$, changing slightly to less positive charge $(9.8 \pm 0.6 \mathrm{mV})$. It is worth noting that positive charge of ZnO NPs in DW became negative regardless of food matrix types when their zeta potentials were measured in MEM. This can be explained by IEP ( $\mathrm{pH} 4.5-5.0)$ of bovine serum albumin present in MEM $[23,27,28]$. Therefore, the interaction effect on the zeta potentials of $\mathrm{ZnO}$ NPs under cell culture condition seems to be minor.

\subsection{Solubility of $\mathrm{ZnO} N$ Ps in Food Proteins}

The solubilities of $\mathrm{ZnO}$ NPs interacted with food proteins or glucose increased in order of those in DW $<$ MEM $<$ ALF (Figure 2A-C). High solubility of ZnO NPs in ALF (pH 4.5) is likely to be associated with their rapid dissolution property under acidic condition [29-32]. On the other hand, the solubilities of ZnO NPs in in vitro digestion fluids such as saliva, gastric, and intestinal fluids were highly different (Figure 2D). The solubilities of ZnO NPs in saliva and intestinal fluid were low, but increased dramatically to $98 \%$ in the gastric fluid. These results can also be explained by low and high dissolution properties of $\mathrm{ZnO}$ under alkaline and acidic conditions, respectively $[30,32,33]$. Slightly but significantly increased solubilities were found by the interactions between $\mathrm{ZnO}$ NPs and food proteins in the intestinal fluid, although the solubilities are low ( $3.4 \%$ in DW versus $3.8-4.5 \%$ in matrices). 

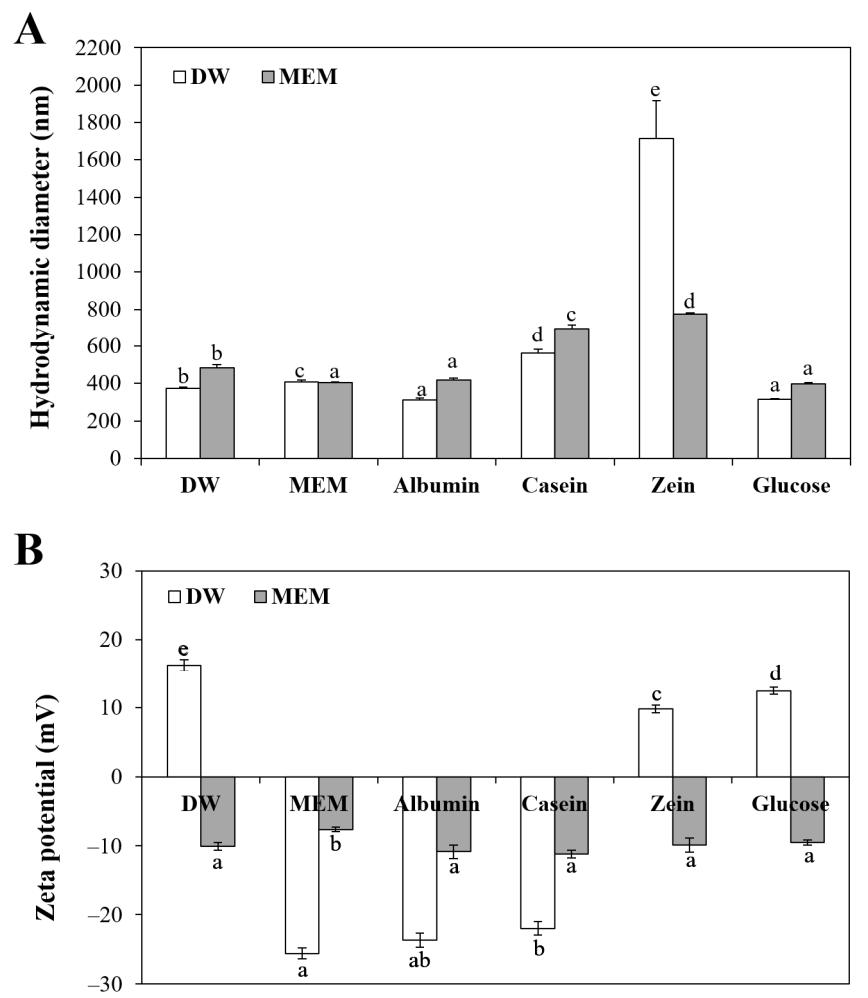

Figure 1. (A) Hydrodynamic diameters and (B) zeta potentials of ZnO NPs in food proteins or glucose, as measured by dilution in distilled water (DW) or cell culture minimum essential medium $(\mathrm{MEM})$. Different lowercase letters (a-e) indicate significant differences among different matrices $(p<0.05)$.
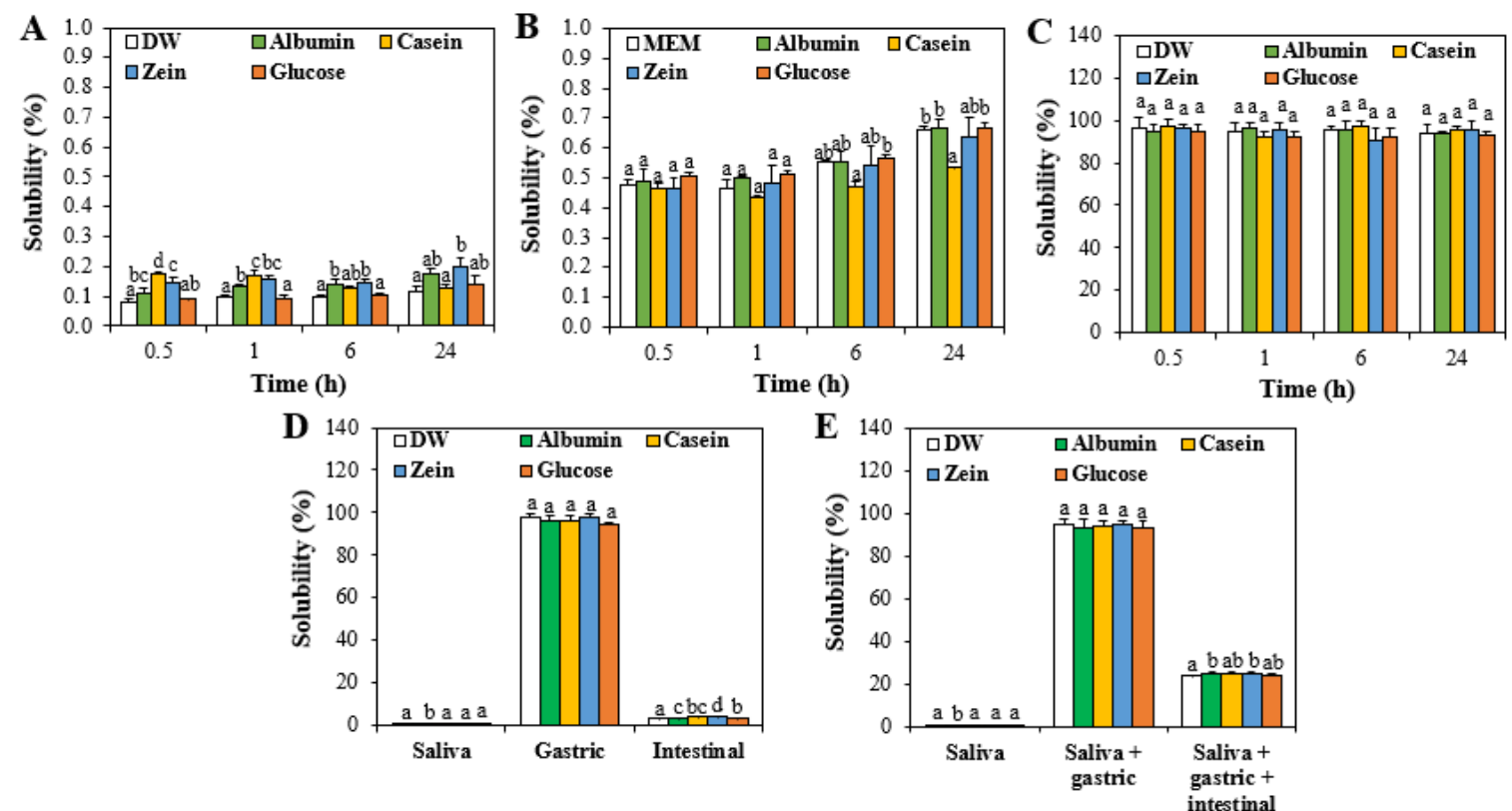

Figure 2. In vitro solubilities of $\mathrm{ZnO}$ NPs $(5 \mathrm{mg} / \mathrm{mL})$ interacted with food proteins or glucose in (A) distilled water (DW), (B) cell culture minimum essential medium (MEM), (C) artificial lysosomal fluid (ALF), (D) simulated digestion fluids, and $(\mathrm{E})$ in vitro three consecutive digestion fluids at $37^{\circ} \mathrm{C}$. Different lowercase letters $(\mathrm{a}-\mathrm{d})$ indicate significant differences among different matrices $(p<0.05)$.

When the solubilities of $\mathrm{ZnO}$ NPs was evaluated in three consecutive digestion fluids, their extremely low dissolution $(\sim 0.1 \%)$ in saliva, high dissolution in saliva followed 
by gastric fluid up to $\sim 95 \%$, and $\sim 25 \%$ dissolution in saliva followed by gastric and intestinal fluids were found (Figure 2E). The interaction effect on the solubility was not remarkable. High solubility of ZnO NPs in the gastric fluid is surely attributed to their high dissolution property in acids, as observed in their high solubility in ALF (Figure 2C). Meanwhile, decreased solubility of ZnO NPs in three consecutive fluids compared with that in saliva followed by gastric fluid can be explained by formation of $\mathrm{Zn}$ aggregates with carbonate or phosphate anions present in simulated gastrointestinal fluids (Table S2). It was demonstrated that dissolved $\mathrm{Zn}$ ions rapidly react with carbonate or phosphate ions at equivalent levels to form $\mathrm{Zn}_{4} \mathrm{CO}_{3}(\mathrm{OH})_{6} \cdot \mathrm{H}_{2} \mathrm{O}$ or $\mathrm{Zn}_{3}\left(\mathrm{PO}_{4}\right)_{2} \cdot \mathrm{xH}_{2} \mathrm{O}(\mathrm{x}=2$ or 4), which are not soluble under alkaline condition [33]. Hence, dissolved $\mathrm{Zn}$ ions in the gastric fluid could form Zn-carbonate or Zn-phosphate aggregates in three consecutive digestion fluids, thereby reducing total dissolved $\mathrm{Zn}$ ions.

\subsection{Interactions between $\mathrm{ZnO} \mathrm{NPs} \mathrm{and} \mathrm{Food} \mathrm{Proteins}$}

Changes in the fluorescence of food proteins by interaction with ZnO NPs were analyzed since tryptophan residues in proteins exhibit maximum fluorescence at $340 \mathrm{~nm}$. Figure 3 shows that fluorescence quenching (55-63\%) of all proteins occurred just after incubation with $\mathrm{ZnO}$ NPs for $0.02 \mathrm{~h}$, suggesting rapid interactions between $\mathrm{ZnO}$ NPs and food proteins. The highest fluorescence quenching of albumin among three food proteins was found by interaction with $\mathrm{ZnO}$ NPs, indicating high interaction between $\mathrm{ZnO}$ NPs and albumin. The fluorescence quenching ratios of albumin and casein significantly increased as incubation time increased. On the other hand, the quenching ratios of zein decreased after $0.5-24 \mathrm{~h}$, which seems to be resulted from low solubility and large hydrodynamic diameters of zein under aqueous condition (Figure 1A), not really attributed to the interaction [25,26].
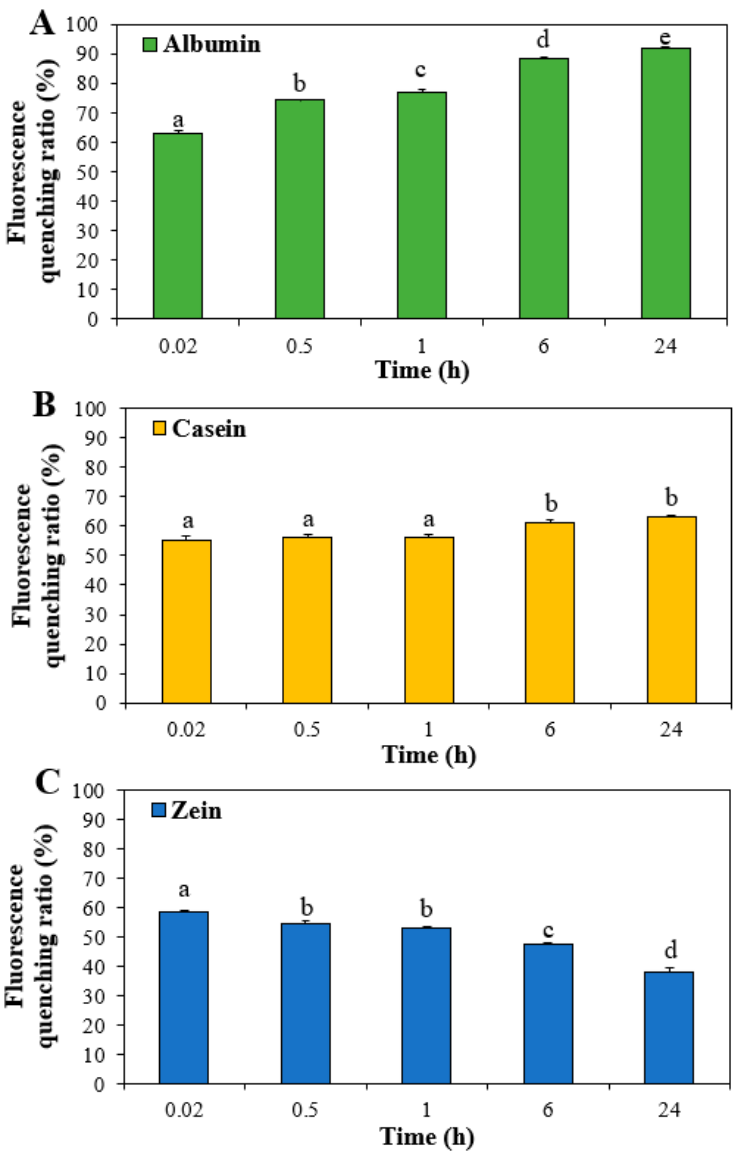

Figure 3. Fluorescence quenching ratios of (A) albumin, (B) casein, and (C) zein by interactions with $\mathrm{ZnO}$ NPs. Different lowercase letters (a-d) indicate significant differences among incubation times $(p<0.05)$. 


\subsection{Primary Structural Stability and Digestion of Food Proteins by Interactions with ZnO NPs}

The interaction effect on the stability of primary structure of food proteins was evaluated by SDS-PAGE. Figure 4A shows that the primary structure of all proteins remained intact by interactions with $\mathrm{ZnO}$ NPs for $24 \mathrm{~h}$. Moreover, albumin, casein, and zein were completely digested by pepsin treatment (Figure $4 \mathrm{~B}-\mathrm{D}$ ). These results suggest that the interactions between ZnO NPs and food proteins did not affect primary structural stability nor digestion efficacy of the proteins.
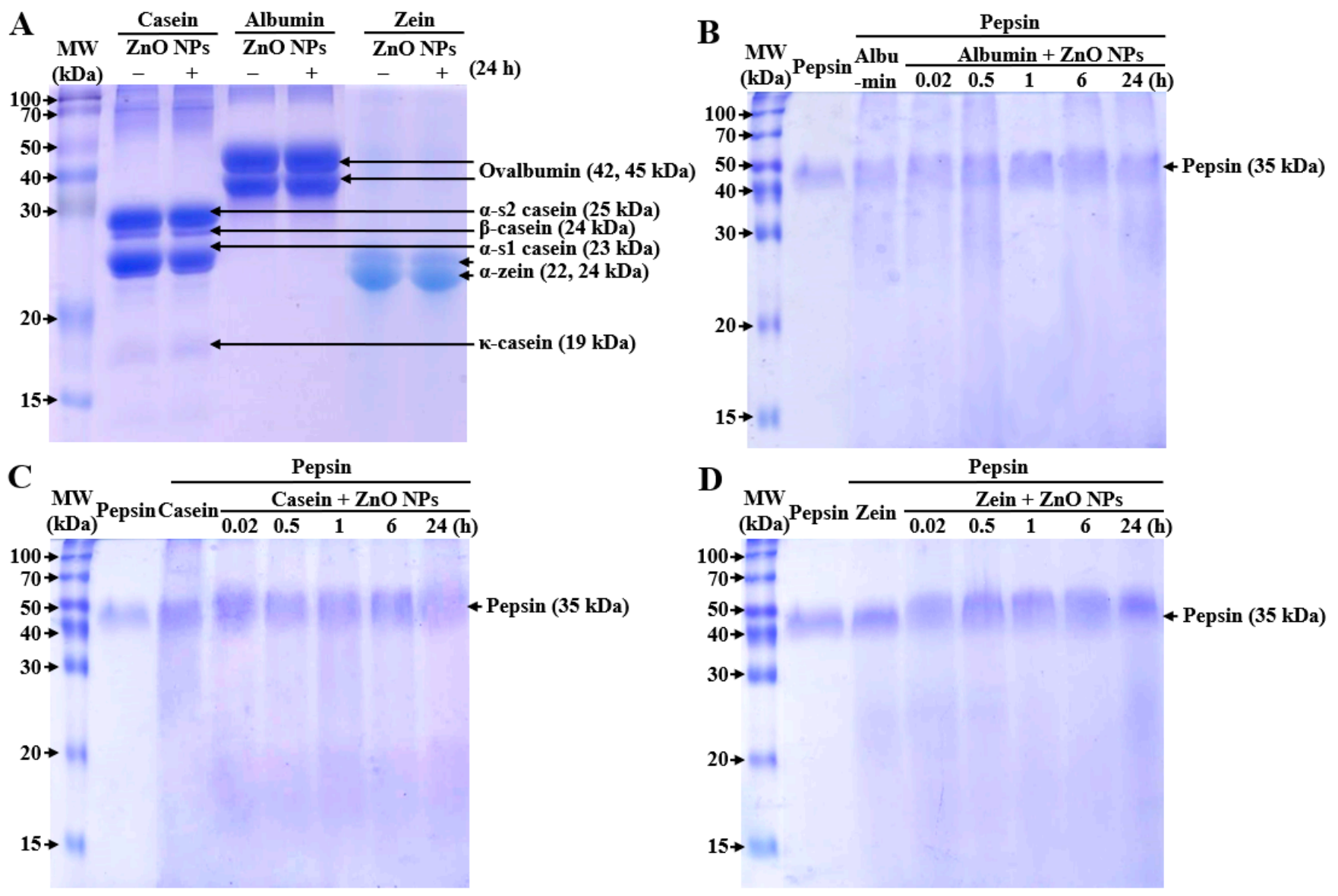

Figure 4. Sodium dodecyl sulfate-polyacrylamide gel electrophoresis (SDS-PAGE) of (A) food proteins interacted with $\mathrm{ZnO}$ NPs for $24 \mathrm{~h}$, and (B) albumin, (C) casein, and (D) zein by interactions with ZnO NPs followed by pepsin treatment for 1 h. MW, molecular weight.

\subsection{Cytotoxicity of ZnO NPs by Interactions with Food Proteins}

The effect of the interactions on cytotoxicity was evaluated in terms of cell proliferation inhibition, LDH release, and ROS generation. The results demonstrate that ZnO NPs in food proteins or glucose significantly inhibited cell proliferation at more than $63 \mu \mathrm{g} / \mathrm{mL}$ (Figure 5A). However, ZnO NPs in casein or zein had statistically low effect on cell proliferation at $125-500 \mu \mathrm{g} / \mathrm{mL}$. Significantly increased LDH release and ROS generation were induced by $\mathrm{ZnO}$ NPs in food matrices at more than $125 \mu \mathrm{g} / \mathrm{mL}$ (Figure $5 \mathrm{~B}, \mathrm{C}$ ). The highest $\mathrm{LDH}$ release and ROS generation were found when $\mathrm{ZnO}$ NPs were interacted with albumin or glucose, followed by interaction with MEM. Relatively low cytotoxicity of $\mathrm{ZnO}$ NPs in casein or zein was found in all cases, probably related to their large hydrodynamic diameters, namely, high aggregate fates (Figure 1A) and relatively weak protein-NP interactions (Figure 3). In other words, high interaction between $\mathrm{ZnO} N P s$ and albumin (Figure 3A) induced small hydrodynamic diameters (Figure 1A), which could increase the cytotoxicity of ZnO NPs (Figure 5). It is interesting to note that ZnO NPs in casein had no effects on LDH release (Figure 5B) and ROS generation (Figure 5C) even at the 
highest concentration tested and only inhibited cell proliferation (Figure 5A). It is probable that ZnO NPs in casein only cover the surface of cell membranes, thereby inhibiting cell proliferation without causing cell death or ROS generation. Hence, casein might be an effective matrix to reduce the cytotoxicity of ZnO NPs. All cytotoxicity results suggest the cytotoxicity of ZnO NPs could be modulated by interactions with food matrices.
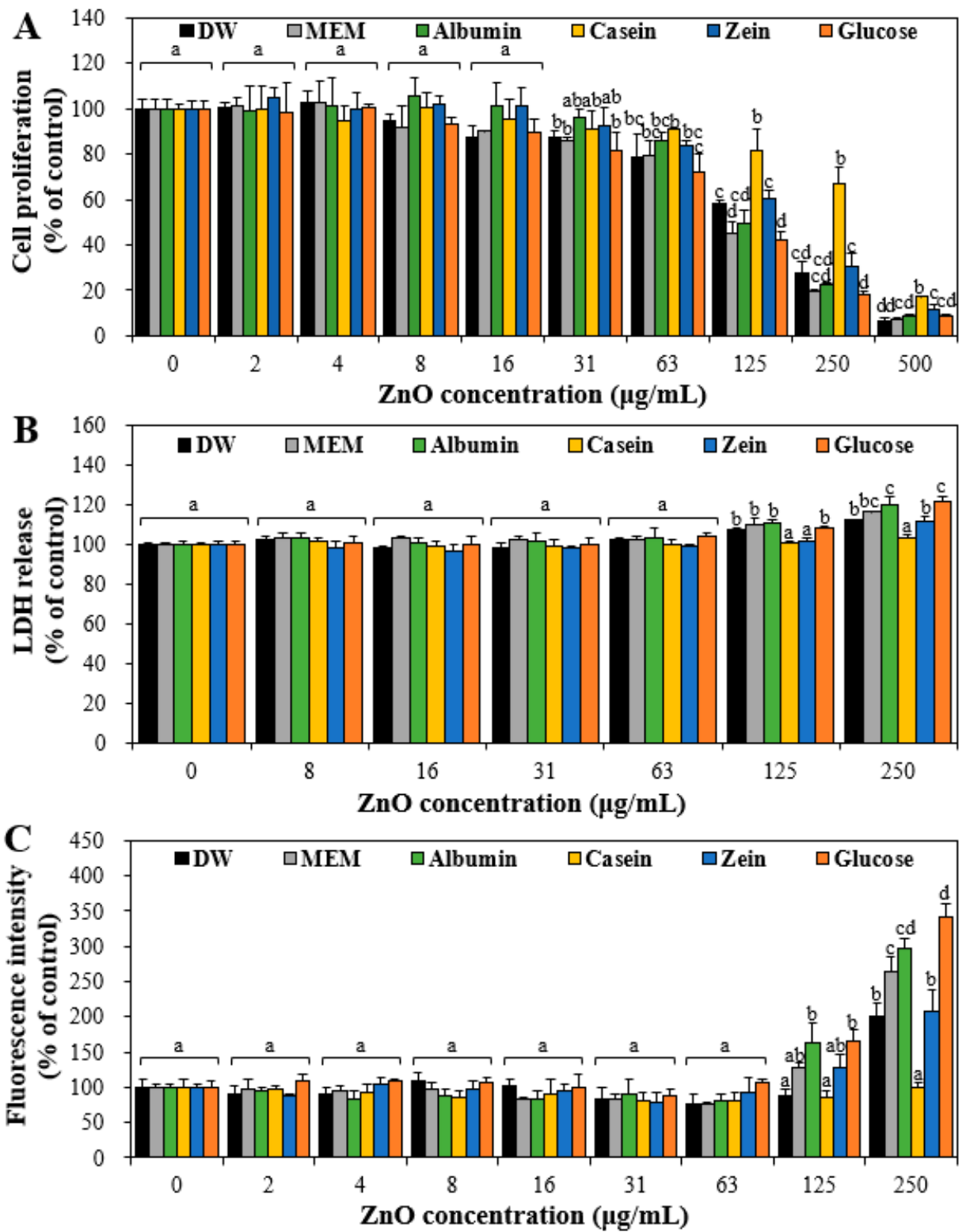

Figure 5. Effects of interactions between ZnO NPs and food proteins or glucose on (A) cell proliferation, $(\mathbf{B})$ lactate dehydrogenase $(\mathrm{LDH})$ release, and $(\mathbf{C})$ reactive oxygen species (ROS) generation in Caco-2 cells after $24 \mathrm{~h}$. Cells without ZnO NPs were used as controls. Different lowercase letters (a-d) indicate significant differences among control and ZnO NPs interacted with DW, MEM, food proteins, or glucose $(p<0.05)$.

\subsection{Cellular Uptake of ZnO NPs by Interactions with Food Proteins}

The effect of the interactions on cellular uptake of ZnO NPs was evaluated by measuring total intracellular Zn levels using ICP-AES. Figure 6 demonstrates that cellular uptake of ZnO NPs significantly enhanced by interactions with matrices, with an order of DW, casein, and zein $<$ MEM < albumin and glucose. This result is very likely to be associated with small hydrodynamic diameters of ZnO NPs in albumin or glucose (Figure 1A), which facilitate efficient cellular internalization. Size-dependent cellular uptake of NPs has been 
well reported, showing efficient higher uptake of NPs than bulk-sized particles [34,35]. Based on DLS, cytotoxicity, fluorescence quenching, and cellular uptake results, albumin seems to strongly interact with $\mathrm{ZnO} N \mathrm{NPs}$, leading to enhanced cellular uptake related to small hydrodynamic diameters. However, the high cellular uptake of $\mathrm{ZnO} N P s$ in albumin could cause high cytotoxicity (Figure 5). These results are highly consistent with those obtained by ZnO NPs in glucose in our previous report, demonstrating small hydrodynamic diameters, high cellular uptake, and high cytotoxicity of ZnO NPs in glucose compared with those in other saccharides [9].

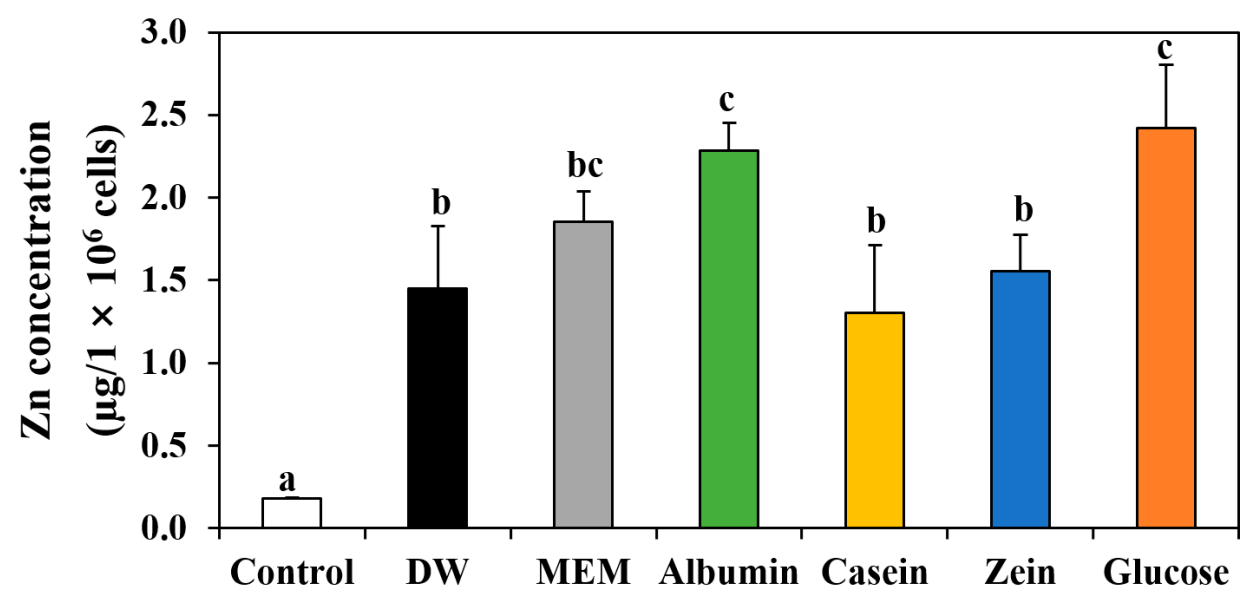

Figure 6. Effect of interactions between $\mathrm{ZnO}$ NPs and food proteins or glucose on cellular uptake in Caco-2 cells after $6 \mathrm{~h}$, as determined by analyzing total intracellular Zn levels using inductively coupled plasma-atomic emission spectroscopy (ICP-AES). Cells without ZnO NPs were used as a control. Different lowercase letters $(\mathrm{a}-\mathrm{c})$ indicate significant differences among control and $\mathrm{ZnO}$ NPs interacted with DW, MEM, food proteins, or glucose $(p<0.05)$.

\subsection{Intestinal Transport of $\mathrm{ZnO} N$ Ps by Interactions with Food Proteins}

The effect of the interactions on intestinal transport of $\mathrm{ZnO} N P s$ was evaluated using Caco-2 monolayer and FAE models, respectively. Intestinal transport amounts of ZnO NPs in food matrices by $\mathrm{M}$ cells were significantly higher than those by Caco-2 monolayers in all cases, indicating the major transport pathway of ZnO NPs by M cells (Figure 7A), which is in good agreement with our previous report $[29,36]$. On the other hand, ZnO NPs in albumin or glucose showed significantly high intestinal transportation compared with those in other matrices. When total transported levels though both Caco-2 monolayer and $\mathrm{M}$ cells were combined, the highest transport of $\mathrm{ZnO}$ NPs by interaction with albumin or glucose was confirmed, followed by interactions with MEM > DW, casein, and zein (Figure 7B). This result is highly consistent with the cellular uptake result (Figure 6). Hence, high interaction between ZnO NPs and albumin contributes towards exhibiting small hydrodynamic diameters, high cellular uptake, high cytotoxicity, and high intestinal transport, which were also reported by the interaction between $\mathrm{ZnO}$ NPs and glucose [9].

\subsection{Toxicokinetics of $\mathrm{ZnO}$ NPs by Interactions with Food Matrices}

The effect of the interactions on toxicokinetics of ZnO NPs was evaluated after a single-dose oral administration in rats. Since only albumin among food proteins tested was found to significantly enhance cellular uptake and intestinal transport, the toxicokinetics of $\mathrm{ZnO}$ NPs in albumin was further evaluated and compared with those of ZnO NPs in glucose. The dose $(100 \mathrm{mg} / \mathrm{kg})$ was selected based on our previous report, showing no acute oral toxicity [37]. The result demonstrates that ZnO NPs in DW and albumin reached peak concentrations at 1.3 and $1.0 \mathrm{~h}$, respectively, and returned to normal levels after $6 \mathrm{~h}$ (Figure 8). Meanwhile, the maximum concentration of $\mathrm{ZnO}$ NPs in glucose was found at $3.5 \mathrm{~h}$ and the concentration decreased to basal level after $10 \mathrm{~h}$, showing higher absorption amount compared with those of $\mathrm{ZnO}$ in DW or albumin. Toxicokinetic parameters also 
confirm these results, showing significantly higher $C_{\max }, T_{\max }, A U C, T_{1 / 2}, M R T, C L / F$, and absorption of $\mathrm{ZnO}$ NPs in glucose than those of $\mathrm{ZnO}$ in DW or albumin (Table 1). No significant differences in all toxicokinetic parameters between $\mathrm{ZnO}$ in $\mathrm{DW}$ and $\mathrm{ZnO}$ in albumin were found $(p>0.05)$. These results indicate that the interaction between $\mathrm{ZnO}$ NPs and glucose could enhance in vivo oral absorption as previously reported [8], but $\mathrm{ZnO}$ interaction with albumin did not affect toxicokinetic behaviors. These results are contradictory to in vitro cellular uptake and intestinal transport results (Figures 6 and 7). It is probable that the interaction between $\mathrm{ZnO}$ NPs and albumin is not strong enough to enhance in vivo oral toxicokinetics, requiring further study on the interaction mechanisms.
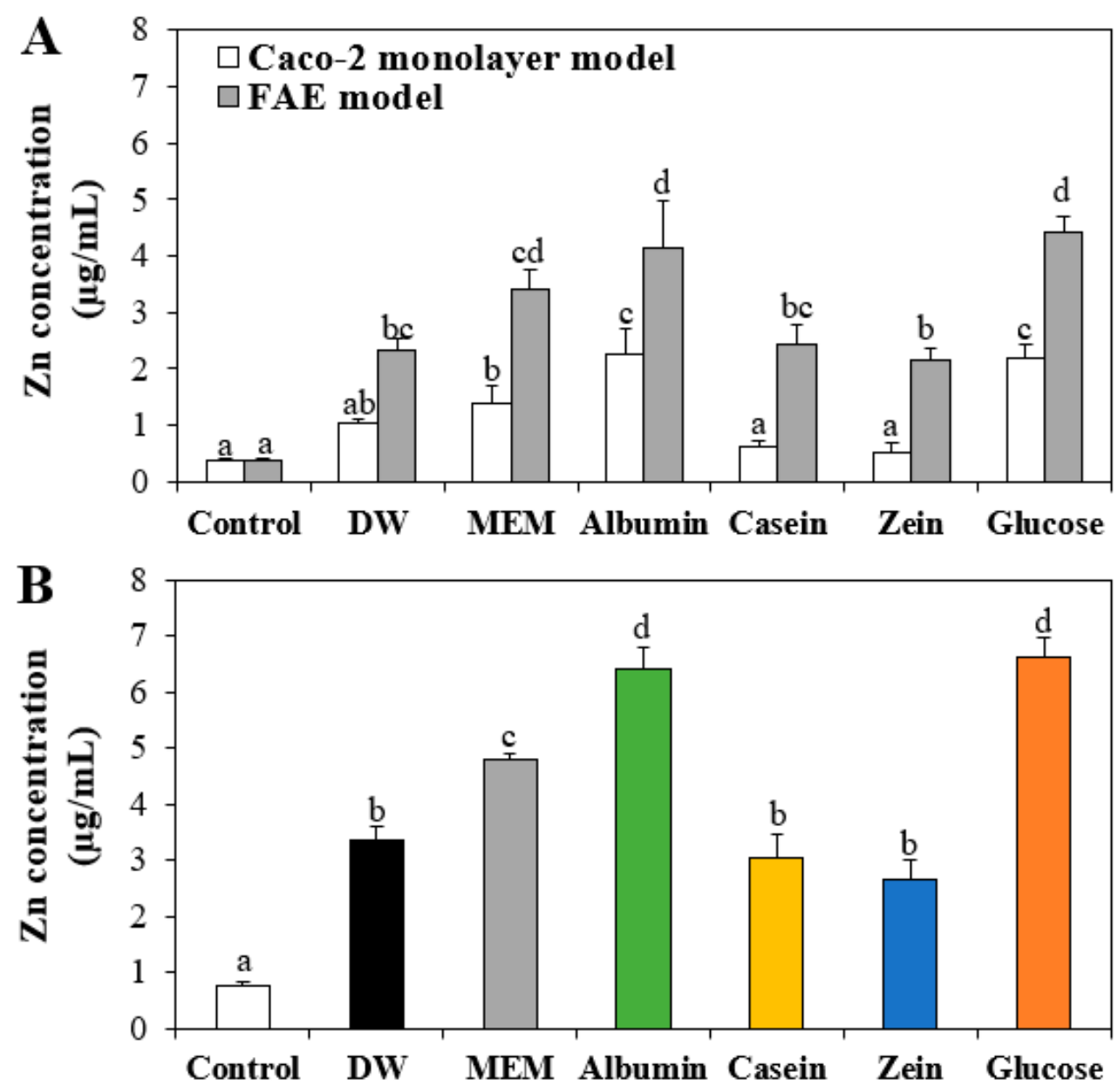

Figure 7. Effect of interactions between $\mathrm{ZnO}$ NPs and food proteins or glucose on (A) intestinal transport of ZnO NPs using in vitro models of Caco-2 monolayers and human follicle-associated epithelium (FAE) and (B) total combined intestinal transport amounts through both Caco-2 monolayer and FAE models after $6 \mathrm{~h}$. Cells without ZnO NPs were used as controls. Different lowercase letters $(a-d)$ indicate significant differences among control and ZnO NPs interacted with DW, MEM, food proteins, or glucose $(p<0.05)$. 


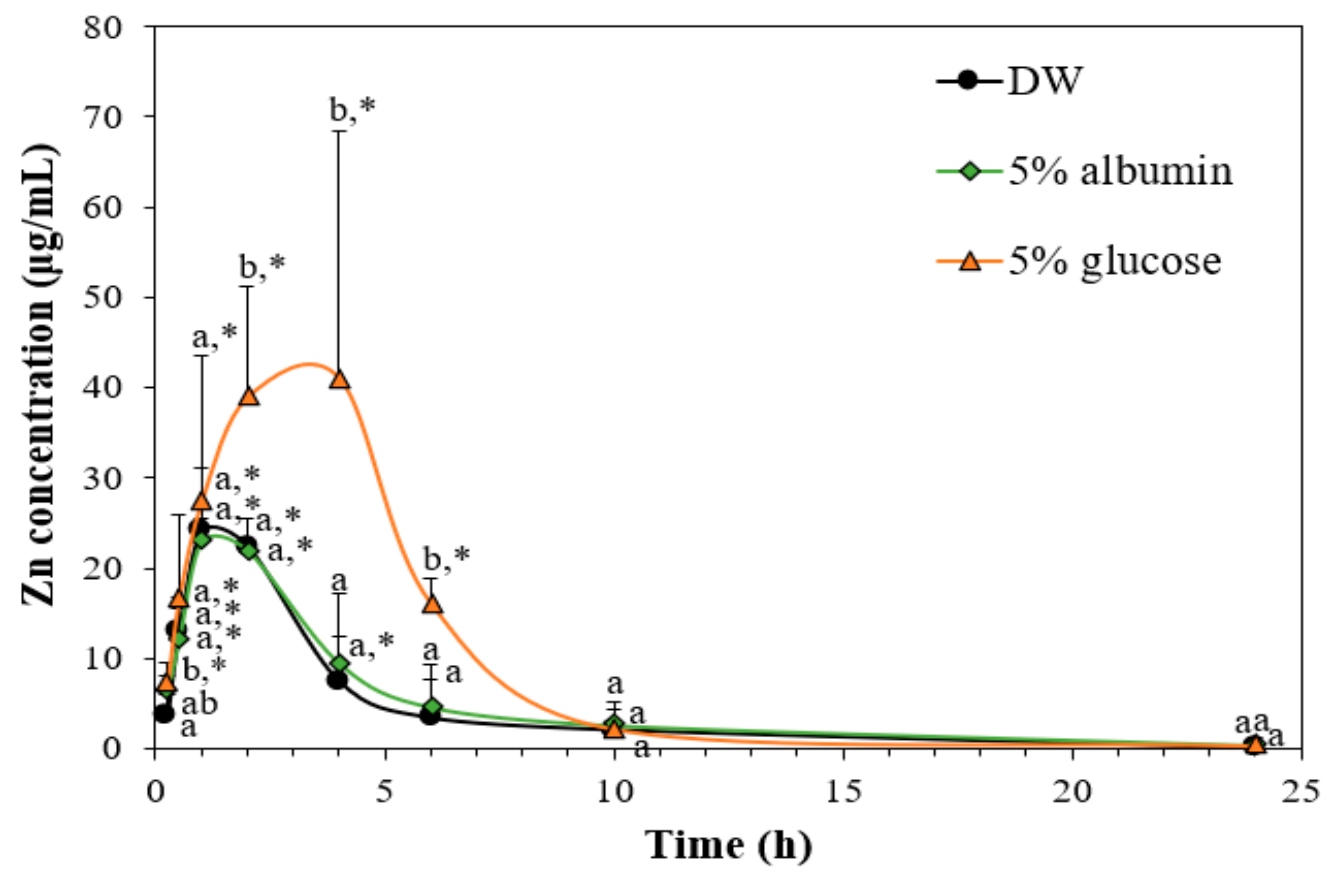

Figure 8. Effect of interactions between ZnO NPs and albumin or glucose on toxicokinetics of ZnO NPs after a single dose $(100 \mathrm{mg} / \mathrm{kg})$ oral administration in rats. Different lowercase letters $(\mathrm{a}, \mathrm{b})$ indicate significant differences among ZnO NPs interacted with DW, albumin, or glucose $(p<0.05)$. ${ }^{*}$ Significant differences compared with untreated control $(p<0.05)$.

Table 1. Toxicokinetic parameters and oral absorption after a single dose ( $100 \mathrm{mg} / \mathrm{kg}$ ) oral administration of ZnO NPs interacted with DW, albumin, or glucose in rats.

\begin{tabular}{cccc}
\hline $\begin{array}{c}\text { Toxicokinetic } \\
\text { Parameters }\end{array}$ & DW & 5\% Albumin & 5\% Glucose \\
\hline $\mathrm{C}_{\max }(\mu \mathrm{g} / \mathrm{mL})$ & $25.3 \pm 3.1^{\mathrm{a}}$ & $25.3 \pm 2.1^{\mathrm{a}}$ & $41.9 \pm 4.6^{\mathrm{b}}$ \\
$\mathrm{T}_{\max }(\mathrm{h})$ & $1.3 \pm 0.5^{\mathrm{a}}$ & $1.0 \pm 0.0^{\mathrm{a}}$ & $3.5 \pm 1.0^{\mathrm{b}}$ \\
$\mathrm{AUC}(\mathrm{h} \times \mu \mathrm{g} / \mathrm{mL})$ & $132.8 \pm 27.1^{\mathrm{a}}$ & $126.5 \pm 18.2^{\mathrm{a}}$ & $280.9 \pm 49.8^{\mathrm{b}}$ \\
$\mathrm{T}_{1 / 2}(\mathrm{~h})$ & $2.5 \pm 0.0^{\mathrm{a}}$ & $2.7 \pm 0.2^{\mathrm{a}}$ & $4.5 \pm 0.4^{\mathrm{b}}$ \\
$\mathrm{MRT}(\mathrm{h})$ & $4.0 \pm 0.4^{\mathrm{a}}$ & $4.3 \pm 0.2^{\mathrm{a}}$ & $5.8 \pm 0.7^{\mathrm{b}}$ \\
$\mathrm{CL} / \mathrm{F}(\mathrm{mL} / \mathrm{h})$ & $625.2 \pm 151.1^{\mathrm{a}}$ & $641.1 \pm 82.3^{\mathrm{a}}$ & $256.6 \pm 24.0^{\mathrm{b}}$ \\
Absorption $(\%)$ & $8.9 \pm 1.9^{\mathrm{a}}$ & $8.4 \pm 0.3^{\mathrm{a}}$ & $18.8 \pm 3.1^{\mathrm{b}}$ \\
\hline
\end{tabular}

Different lower-case letters $\left({ }^{a}, \mathrm{~b}\right)$ indicate significant differences among ZnO NPs interacted with DW, albumin, or glucose $(p<0.05)$. DW, distilled water; $\mathrm{C}_{\max }$, maximum concentration; $\mathrm{T}_{\max }$, time to maximum concentration; AUC, area under the plasma concentration-time curve; $\mathrm{T}_{1 / 2}$, half-life; MRT, mean residence time; CL/F, apparent clearance.

\subsection{Oral Toxicity of ZnO NPs by Interactions with Food Matrices}

The effect of the interactions on oral toxicity of ZnO NPs was evaluated after oral administration in rats for 14 consecutive days. The most interacted protein with $\mathrm{ZnO}$ NPs, albumin, was selected for oral toxicity, together with glucose that was determined to enhance cellular uptake, intestinal transport, and oral absorption of ZnO NPs in this study and in our previous report [9]. The same dose $(100 \mathrm{mg} / \mathrm{kg})$ for toxicokinetics was used for oral toxicity study based on our previous research [36]. Figure 9 demonstrates that body weight gain, food intake, and water consumption were not significantly affected by $\mathrm{ZnO}$ NPs in DW, albumin, or glucose. No significant changes in organo-somatic indices among control and ZnO NPs in DW, albumin, or glucose were also found (Table 2), suggesting their low oral toxicity. 

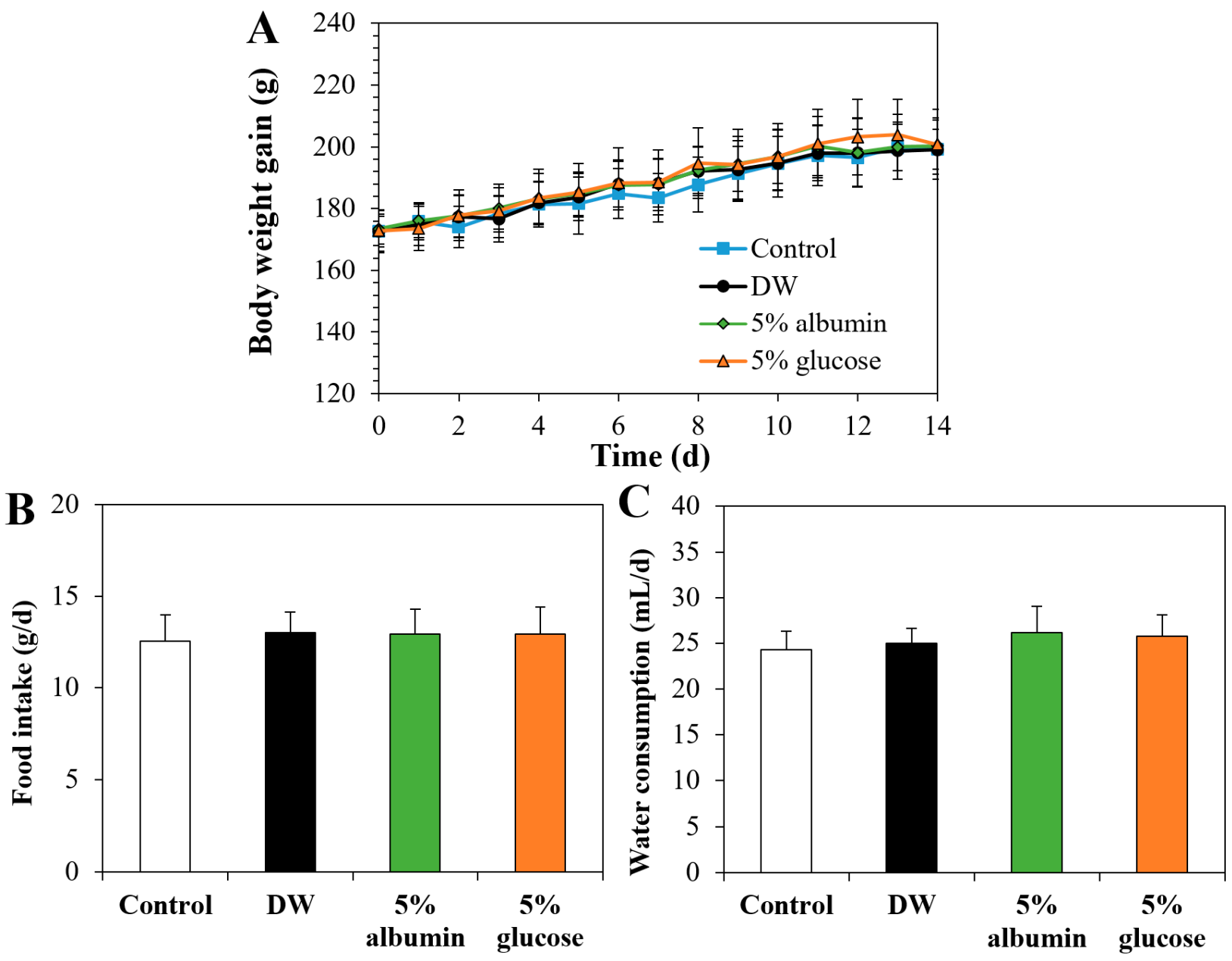

Figure 9. Changes in (A) body weight gains, (B) food intake, and (C) water consumption of rats after oral administration of ZnO NPs (100 mg/kg) interacted with DW, albumin, or glucose for 14 consecutive days. Rats administered an equivalent volume of DW without $\mathrm{ZnO}$ NPs were used as controls. No significant differences among untreated control and $\mathrm{ZnO}$ interacted with DW, albumin, or glucose were found $(p>0.05)$.

Table 2. Organo-somatic indices of rats after oral administration of $\mathrm{ZnO}$ NPs $(100 \mathrm{mg} / \mathrm{kg})$ interacted with DW, albumin, or glucose for 14 consecutive days.

\begin{tabular}{ccccc}
\hline Organ & Control & DW & $\mathbf{5 \%}$ Albumin & $\mathbf{5 \%}$ Glucose \\
\hline Brain & $0.8 \pm 0.0$ & $0.8 \pm 0.1$ & $0.8 \pm 0.1$ & $0.8 \pm 0.1$ \\
Heart & $0.4 \pm 0.0$ & $0.4 \pm 0.0$ & $0.4 \pm 0.0$ & $0.4 \pm 0.0$ \\
Kidney & $0.8 \pm 0.1$ & $0.8 \pm 0.0$ & $0.8 \pm 0.1$ & $0.8 \pm 0.0$ \\
Large intestine & $1.9 \pm 0.3$ & $1.6 \pm 0.3$ & $1.7 \pm 0.3$ & $1.5 \pm 0.6$ \\
Liver & $3.7 \pm 0.2$ & $3.8 \pm 0.3$ & $3.9 \pm 0.3$ & $3.9 \pm 0.2$ \\
Lung & $0.6 \pm 0.1$ & $0.6 \pm 0.1$ & $0.6 \pm 0.1$ & $0.6 \pm 0.1$ \\
Ovary & $0.1 \pm 0.0$ & $0.1 \pm 0.0$ & $0.1 \pm 0.0$ & $0.1 \pm 0.0$ \\
Small intestine & $4.1 \pm 0.4$ & $4.2 \pm 0.3$ & $4.3 \pm 0.3$ & $4.1 \pm 0.3$ \\
Spleen & $0.3 \pm 0.1$ & $0.3 \pm 0.0$ & $0.3 \pm 0.0$ & $0.3 \pm 0.1$ \\
Stomach & $1.7 \pm 0.3$ & $1.7 \pm 0.6$ & $1.5 \pm 0.4$ & $1.3 \pm 0.3$ \\
\hline
\end{tabular}

No significant differences among untreated control, $\mathrm{ZnO}$ interacted with $\mathrm{DW}$, albumin, or glucose were found $(p>0.05)$.

Hematological and coagulation time values reveal no significant increase or decrease in rats administered $\mathrm{ZnO}$ NPs in DW compared with those of non-treated control rats, except significant increase in eosinophils (EO) (Table 3). All hematological and coagulation time values were not significantly affected by interactions between $\mathrm{ZnO}$ NPs and albumin or glucose compared with those in the control group. Serum biochemical parameters show 
that total protein (TP), albumin (ALB), alkaline phosphatase (ALP), creatine (CREA), blood urea nitrogen (BUN), and calcium (CA) values decreased, whereas significantly increased inorganic phosphorus (IP) value was found in rats administered ZnO NPs in DW compared with those in non-treated controls (Table 4). Significant decrease in TP, ALB, ALP, and CA was also found in ZnO NPs in albumin or glucose-treated rats. Decreased triglyceride (TG) value was only observed in rats treated with $\mathrm{ZnO}$ NPs in albumin. It is worth noting that reduced TP, ALB, ALP, CREA, BUN, and TG values are not considered toxic, but they are rather related to individual variation $[38,39]$. Changes in CA and IP values by ZnO NPs in DW, albumin, or glucose seems to be minor.

Histopathological findings show that minimal tubular degeneration and inflammatory cell infiltration or minimal cortical scar were observed, but only in one rat among five rats administered ZnO NPs in albumin or glucose (Table 5, Figure 10). Furthermore, the severity of the lesions was mild, and these histopathological findings are often observed as background lesions [40-42]. It is interesting to note that no abnormality was detected in rats treated with ZnO NPs in DW (Table 5, Figure 10). Taken together, ZnO NPs in DW did not cause acute oral toxicity at dose level tested, and the interactions between $\mathrm{ZnO}$ NPs albumin or glucose did not induce higher oral toxicity than ZnO NPs in DW. Similar toxicokinetic behaviors of ZnO NPs in DW to those of ZnO NPs in albumin could explain these oral toxicity results (Figure 8, Table 2). Moreover, it is likely that enhanced oral absorption amount of $\mathrm{ZnO}$ NPs in glucose was not enough to affect oral toxicity of $\mathrm{ZnO}$ NPs. It is also probable that the interaction was not strong enough to affect in vivo acute oral toxicity of ZnO NPs. Further study is required to determine the interaction mechanism between $\mathrm{ZnO} N P s$ and food matrices and to ascertain the interaction effects on chronic oral toxicity of $\mathrm{ZnO}$ NPs. 
Table 3. Hematological and coagulation time values of rats after oral administration of ZnO NPs (100 mg/kg) interacted with DW, albumin, or glucose for 14 consecutive days.

\begin{tabular}{|c|c|c|c|c|c|c|c|c|c|c|c|c|c|c|c|c|}
\hline \multirow{2}{*}{ Groups } & \multirow{2}{*}{$\frac{\mathrm{WBC}}{\left(10^{3} / \mu \mathrm{L}\right)}$} & \multicolumn{5}{|c|}{ WBC Differential Counting (\%) } & \multirow{2}{*}{$\begin{array}{c}\text { RBC } \\
\left(10^{6} / \mu \mathrm{L}\right)\end{array}$} & \multirow{2}{*}{$\begin{array}{c}\mathrm{Hb} \\
(\mathrm{g} / \mathrm{dL})\end{array}$} & \multirow{2}{*}{$\begin{array}{c}\text { HCT } \\
(\%)\end{array}$} & \multirow{2}{*}{$\begin{array}{c}\text { MCV } \\
\text { (fL) }\end{array}$} & \multirow{2}{*}{$\begin{array}{c}\text { MCH } \\
\text { (pg) }\end{array}$} & \multirow{2}{*}{$\begin{array}{c}\text { MCHC } \\
\text { (g/dL) }\end{array}$} & \multirow{2}{*}{$\begin{array}{c}\text { RETI } \\
(\%)\end{array}$} & \multirow{2}{*}{$\begin{array}{c}\text { PLT } \\
\left(10^{3} / \mu \mathrm{L}\right)\end{array}$} & \multirow{2}{*}{$\begin{array}{l}\text { PT } \\
(s)\end{array}$} & \multirow{2}{*}{$\begin{array}{c}\text { APTT } \\
\text { (s) }\end{array}$} \\
\hline & & NE & LY & MO & EO & BA & & & & & & & & & & \\
\hline \multirow{2}{*}{ Control } & 6.89 & 10.3 & 85.0 & 1.9 & 1.3 & 0.6 & 7.08 & 13.8 & 44.4 & 62.6 & 19.5 & 31.1 & 3.25 & 950 & 17.4 & 38.5 \\
\hline & \pm 0.86 & \pm 1.9 & \pm 1.9 & \pm 0.3 & \pm 0.4 & \pm 0.1 & \pm 0.19 & \pm 0.5 & \pm 1.7 & \pm 1.4 & \pm 0.4 & \pm 0.5 & \pm 0.88 & \pm 151 & \pm 0.5 & \pm 2.7 \\
\hline \multirow{2}{*}{ DW } & 6.47 & 14.6 & 78.3 & 2.0 & 3.1 & 0.8 & 7.04 & 13.6 & 43.8 & 62.2 & 19.3 & 31.0 & 2.72 & 902 & 17.3 & 39.0 \\
\hline & \pm 1.21 & \pm 5.0 & \pm 5.4 & \pm 0.3 & $\pm 0.9^{* *}$ & \pm 0.3 & \pm 0.41 & \pm 1.0 & \pm 2.9 & \pm 1.6 & \pm 0.5 & \pm 0.6 & \pm 0.22 & \pm 300 & \pm 0.9 & \pm 7.3 \\
\hline $5 \%$ & 6.74 & 7.9 & 86.4 & 2.0 & 1.8 & 0.7 & 7.27 & 14.0 & 45.4 & 62.5 & 19.2 & 30.8 & 2.65 & 1056 & 17.1 & 46.2 \\
\hline albumin & \pm 1.22 & \pm 1.8 & \pm 1.5 & \pm 0.2 & \pm 0.4 & \pm 0.4 & \pm 0.34 & \pm 0.5 & \pm 1.3 & \pm 1.3 & \pm 0.4 & \pm 0.4 & \pm 0.55 & \pm 76 & \pm 0.3 & \pm 4.8 \\
\hline \multirow{2}{*}{$5 \%$ glucose } & 6.79 & 9.5 & 83.7 & 2.1 & 2.2 & 0.8 & 7.25 & 13.9 & 44.5 & 61.5 & 19.2 & 31.2 & 2.97 & 1171 & 16.7 & 40.4 \\
\hline & \pm 1.37 & \pm 1.2 & \pm 1.1 & \pm 0.5 & \pm 0.4 & \pm 0.4 & \pm 0.33 & \pm 0.6 & \pm 2.0 & \pm 1.1 & \pm 0.5 & \pm 0.6 & \pm 0.60 & \pm 121 & \pm 0.3 & \pm 13.1 \\
\hline
\end{tabular}

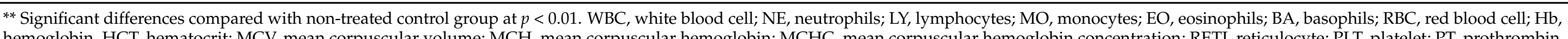
hemoglobin, HCT, hematocrit; MCV, mean corpuscular
time; APTT, activated partial thromboplastin time.

Table 4. Serum biochemical values of rats after oral administration of ZnO NPs (100 mg/kg) interacted with DW, albumin, or glucose for 14 consecutive days.

\begin{tabular}{|c|c|c|c|c|c|c|c|c|c|c|c|c|c|c|c|c|c|c|}
\hline Grounc & $\mathbf{T P}$ & ALB & A/G & T-BIL & ALP & AST & ALT & CREA & BUN & CHOL & TG & GLU & CA & IP & CK & $\mathrm{Na}$ & $\mathbf{K}$ & $\mathrm{Cl}$ \\
\hline 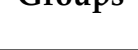 & $(g / d L)$ & (g/dL) & & (mg/dL) & $(\mathrm{U} / \mathrm{L})$ & $(\mathrm{U} / \mathrm{L})$ & $(\mathrm{U} / \mathrm{L})$ & (g/dL) & $(\mathrm{g} / \mathrm{dL})$ & $(g / d L)$ & (g/dL) & $(\mathrm{g} / \mathrm{dL})$ & $(g / d L)$ & $(g / d L)$ & $(\mathrm{IU} / \mathrm{L})$ & \multicolumn{3}{|c|}{$(\mathrm{mmol} / \mathrm{L})(\mathrm{mmol} / \mathrm{L})(\mathrm{mmol} / \mathrm{L})$} \\
\hline Control & $\begin{array}{c}6.8 \\
\pm 0.2\end{array}$ & $\begin{array}{c}4.4 \\
\pm 0.1\end{array}$ & $\begin{array}{c}1.9 \\
\pm 0.1\end{array}$ & $\begin{array}{c}0.0 \\
\pm 0.0\end{array}$ & $\begin{array}{c}783 \\
\pm 131\end{array}$ & $\begin{array}{l}77 \\
\pm 6\end{array}$ & $\begin{array}{l}49 \\
\pm 5\end{array}$ & $\begin{array}{c}0.54 \\
\pm 0.04\end{array}$ & $\begin{array}{c}26.3 \\
\pm 4.7\end{array}$ & $\begin{array}{c}88 \\
\pm 14\end{array}$ & $\begin{array}{c}82 \\
\pm 9\end{array}$ & $\begin{array}{c}299 \\
\pm 33\end{array}$ & $\begin{array}{l}12.7 \\
\pm 0.3\end{array}$ & $\begin{array}{c}9.4 \\
\pm 0.7\end{array}$ & $\begin{array}{c}185 \\
\pm 86\end{array}$ & $\begin{array}{l}147.7 \\
\pm 0.7\end{array}$ & $\begin{array}{c}5.60 \\
\pm 0.30\end{array}$ & $\begin{array}{c}97.4 \\
\pm 0.9\end{array}$ \\
\hline DW & $\begin{array}{c}6.2 \\
\pm 0.1^{* *}\end{array}$ & $\begin{aligned} & 4.1 \\
\pm & 0.1^{* *}\end{aligned}$ & $\begin{array}{c}2.0 \\
\pm 0.1\end{array}$ & $\begin{array}{c}0.0 \\
\pm 0.0\end{array}$ & $\begin{array}{c}550 \\
\pm 63^{*}\end{array}$ & $\begin{array}{l}72 \\
\pm 5\end{array}$ & $\begin{array}{l}48 \\
\pm 4\end{array}$ & $\begin{array}{c}0.48 \\
\pm \underset{*}{*} \\
0.02\end{array}$ & $\begin{array}{c}19.6 \\
\pm 2.8^{*}\end{array}$ & $\begin{array}{l}90 \\
\pm 8\end{array}$ & $\begin{array}{c}66 \\
\pm 15\end{array}$ & $\begin{array}{c}289 \\
\pm 18\end{array}$ & $\begin{array}{c}12.1 \\
\pm 0.3^{*}\end{array}$ & $\begin{array}{c}10.9 \\
\pm 0.8^{*}\end{array}$ & $\begin{array}{c}278 \\
\pm 229\end{array}$ & $\begin{array}{l}147.2 \\
\pm 1.0\end{array}$ & $\begin{array}{c}6.22 \\
\pm 0.22\end{array}$ & $\begin{array}{c}97.9 \\
\pm 1.2\end{array}$ \\
\hline $\begin{array}{c}5 \% \\
\text { albumin } \\
5 \% \\
\text { glucose }\end{array}$ & $\begin{aligned} & 6.2 \\
\pm & 0.2^{* *} \\
& 6.1 \\
\pm & 0.2^{* *}\end{aligned}$ & $\begin{aligned} & 4.1 \\
\pm & 0.2^{* *} \\
& 3.9 \\
\pm & 0.2^{* *}\end{aligned}$ & $\begin{array}{c}1.9 \\
\pm 0.1 \\
1.8 \\
\pm 0.2\end{array}$ & $\begin{array}{c}0.0 \\
\pm 0.0 \\
0.0 \\
\pm 0.0\end{array}$ & $\begin{array}{c}542 \\
\pm 128 \\
592 \\
\pm 114\end{array}$ & $\begin{array}{c}74 \\
\pm 7 \\
71 \\
\pm 10\end{array}$ & $\begin{array}{l}56 \\
\pm 9 \\
48 \\
\pm 6\end{array}$ & $\begin{array}{c}0.49 \\
\pm 0.03 \\
0.50 \\
\pm 0.02\end{array}$ & $\begin{array}{c}25.4 \\
\pm 2.5 \\
20.0 \\
\pm 2.9\end{array}$ & $\begin{array}{c}83 \\
\pm 8 \\
85 \\
\pm 8\end{array}$ & $\begin{array}{c}51 \\
\pm 13 \\
62 \\
\pm 16\end{array}$ & $\begin{array}{c}247 \\
\pm 39 \\
259 \\
\pm 17\end{array}$ & $\begin{array}{c}12.1 \\
\pm 0.3^{*} \\
12.0 \\
\pm 0.2^{*}\end{array}$ & $\begin{array}{c}10.3 \\
\pm 0.8 \\
10.4 \\
\pm 0.8\end{array}$ & $\begin{array}{c}191 \\
\pm 45 \\
209 \\
\pm 39\end{array}$ & $\begin{array}{l}148.0 \\
\pm 1.6 \\
147.3 \\
\pm 1.7\end{array}$ & $\begin{array}{c}5.84 \\
\pm 0.46 \\
5.88 \\
\pm 0.40\end{array}$ & $\begin{array}{c}98.8 \\
\pm 1.2 \\
98.7 \\
\pm 2.1\end{array}$ \\
\hline
\end{tabular}

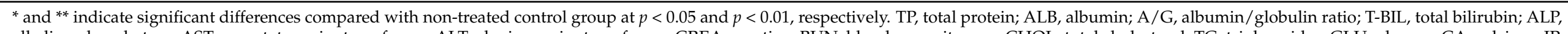

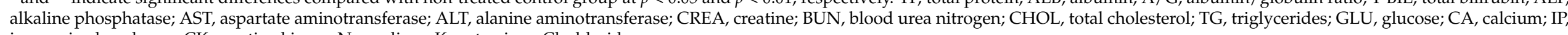
inorganic phosphorus; $\mathrm{CK}$, creatine kinase; $\mathrm{Na}$, sodium; $\mathrm{K}$, potassium; $\mathrm{Cl}$, chloride. 
Table 5. Summary of histopathological findings of rats after oral administration of ZnO NPs (100 mg/kg) interacted with DW, albumin, or glucose for 14 consecutive days.

\begin{tabular}{|c|c|c|c|c|c|c|}
\hline Organs & $\begin{array}{c}\text { Numbers of } \\
\text { Animals }\end{array}$ & $\begin{array}{l}\text { Histopathological } \\
\text { Findings }\end{array}$ & Control & DW & $\begin{array}{c}5 \% \\
\text { Albumin }\end{array}$ & $\begin{array}{c}5 \% \\
\text { Glucose }\end{array}$ \\
\hline Liver & 5 & $\begin{array}{c}\text { No abnormalities } \\
\text { detected }\end{array}$ & 5 & 5 & 5 & 5 \\
\hline \multirow{3}{*}{ Kidney } & \multirow{3}{*}{5} & $\begin{array}{c}\text { No abnormalities } \\
\text { detected }\end{array}$ & 5 & 5 & 4 & 4 \\
\hline & & $\begin{array}{l}\text { Tubular degeneration } \\
\text { and inflammatory cell } \\
\text { infiltration minimal }\end{array}$ & 0 & 0 & 0 & 1 \\
\hline & & Scar, cortical minimal & 0 & 0 & 1 & 0 \\
\hline Lung & 5 & $\begin{array}{c}\text { No abnormalities } \\
\text { detected }\end{array}$ & 5 & 5 & 5 & 5 \\
\hline Spleen & 5 & $\begin{array}{c}\text { No abnormalities } \\
\text { detected }\end{array}$ & 5 & 5 & 5 & 5 \\
\hline
\end{tabular}

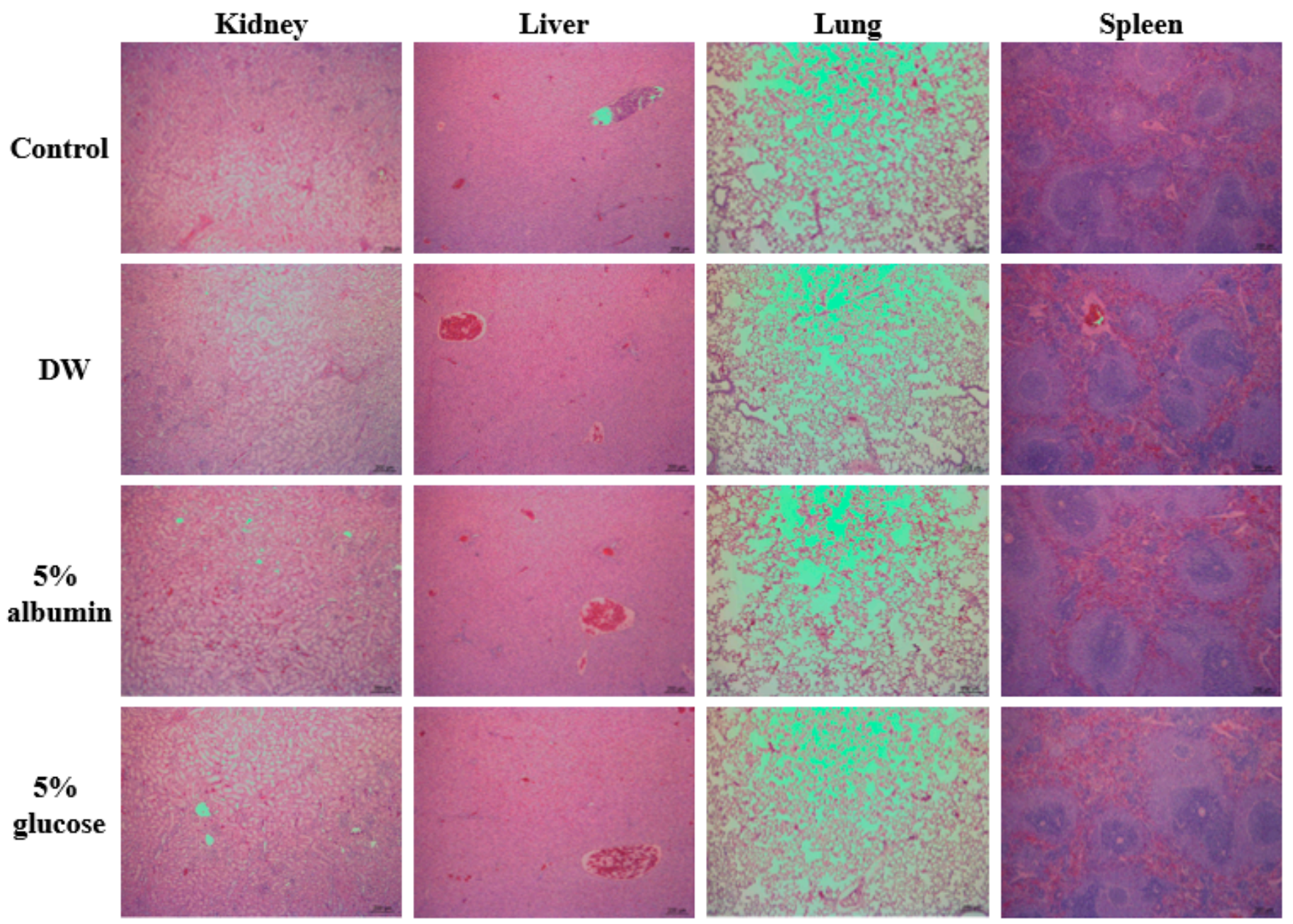

Figure 10. Normal histopathological sections of the kidney, liver, lung, and spleen of the rats after oral administration of ZnO NPs $(100 \mathrm{mg} / \mathrm{kg})$ interacted with DW, albumin, or glucose for 14 consecutive days. Images were magnified at $50 \times$. 


\section{Conclusions}

The interactions between $\mathrm{ZnO}$ NPs and food proteins such as albumin, casein, and zein were investigated and the interactions were compared with that with glucose. The interactions rapidly occurred as evidenced by high fluorescence quenching of all proteins and changes in zeta potentials of ZnO NPs in the presence of proteins, but differently depending on protein types. The interaction between $\mathrm{ZnO}$ NPs and albumin reduced hydrodynamic diameters, causing high cytotoxicity, cellular uptake, and intestinal transport in a similar manner to $\mathrm{ZnO}$ NPs interacted with glucose. The interactions between $\mathrm{ZnO}$ NPs and casein or zein induced high aggregates and reduced cytotoxicity without affecting in vitro cellular uptake and intestinal transport amounts. Oral absorption and toxicokinetic behaviors of $\mathrm{ZnO}$ NPs were not affected by interaction with albumin, contrary to their enhanced oral absorption by interaction with glucose. However, these interactions did not cause acute toxicity after oral administration in rats for 14 consecutive days, suggesting low interaction effect on in vivo acute oral toxicity. Further study is required to determine the interaction mechanism between $\mathrm{ZnO}$ NPs and food matrices and to ascertain the effect of the interactions between $\mathrm{ZnO}$ NPs and food matrices on chronic oral toxicity.

Supplementary Materials: The following are available online at https:/ / www.mdpi.com/article/10 .3390/nano11112922/s1, Figure S1: Scanning electron microscopy (SEM) images and size distribution of ZnO NPs, Table S1: Composition of artificial lysosomal fluid (ALF), Table S2, Composition of simulated digestion fluids.

Author Contributions: Investigation, formal analysis, E.-B.J.; investigation, data curation, validation, J.Y.; conceptualization, supervision, funding acquisition, resources, writing — original draft, writingrevision, S.-J.C. All authors have read and agreed to the published version of the manuscript.

Funding: This research was funded by a grant (20182MFDS404) from the Ministry of Food and Drug Safety in 2021, by the National Research Foundation of Korea (NRF) grant funded by the Korea government (MIST) (2021R1A2C2007192), by Nano Material Technology Development Program (2018M3A7B6051668) of the National Research Foundation (NRF) funded by the Ministry of Science and ICT, and partly by a research grant from Seoul Women's University (2021-0449).

Institutional Review Board Statement: The study was conducted according to the guidelines of the Declaration of Helsinki, and approved by the Institutional Animal Care and Use Committee (IACUC) of the Seoul Women's University (SWU IACUC-2019A-1, 3 April 2019).

Informed Consent Statement: Not applicable.

Data Availability Statement: The data presented in this study are available in the article and Supplementary Materials.

Conflicts of Interest: The authors declare no conflict of interest. The funders had no role in the design of the study; in the collection, analyses, or interpretation of data; in the writing of the manuscript, or in the decision to publish the results.

\section{References}

1. Wojnarowicz, J.; Chudoba, T.; Lojkowski, W. A review of microwave synthesis of zinc oxide nanomaterials: Reactants, process parameters and morphologies. Nanomaterials 2020, 10, 1086. [CrossRef]

2. MacDonald, R.S. The role of zinc in growth and cell proliferation. J. Nutr. 2000, 130, 1500S-1508S. [CrossRef] [PubMed]

3. Dardenne, M. Zinc and immune function. Eur. J. Clin. Nutr. 2002, 56, S20-S23. [CrossRef] [PubMed]

4. Hafeez, B.; Khanif, Y.; Saleem, M. Role of zinc in plant nutrition-a review. J. Exp. Agric. Int. 2013, 3, 374-391. [CrossRef]

5. Faizan, M.; Hayat, S.; Pichtel, J. Effects of zinc oxide nanoparticles on crop plants: A perspective analysis. In Sustainable Agriculture Reviews 41; Springer: New York, NY, USA, 2020; pp. 83-99.

6. Fosmire, G.J. Zinc toxicity. Am. J. Clin. Nutr. 1990, 51, 225-227. [CrossRef]

7. Nriagu, J. Zinc toxicity in humans. In Encyclopedia of Environmental Health, 1st ed.; Nriagu, J., Ed.; Elsevier: Amsterdam, The Netherlands, 2011; pp. 801-807.

8. Maret, W.; Sandstead, H.H. Zinc requirements and the risks and benefits of zinc supplementation. J. Trace Elem. Med. Biol. 2006, 20,3-18. [CrossRef]

9. Go, M.-R.; Yu, J.; Bae, S.-H.; Kim, H.-J.; Choi, S.-J. Effects of interactions between ZnO nanoparticles and saccharides on biological responses. Int. J. Mol. Sci. 2018, 19, 486. [CrossRef] [PubMed] 
10. Bae, S.-H.; Yu, J.; Lee, T.G.; Choi, S.-J. Protein food matrix-ZnO nanoparticle interactions affect protein conformation, but may not be biological responses. J. Mol. Sci. 2018, 19, 3926. [CrossRef]

11. Jung, E.B. Interaction between Food Additive ZnO Nanoparticles and Food Proteins. Master's Thesis, Seoul Women's University, Seoul, Korea, 16 June 2021.

12. Lee, J.-A.; Kim, M.-K.; Song, J.H.; Jo, M.-R.; Yu, J.; Kim, K.-M.; Kim, Y.-R.; Oh, J.-M.; Choi, S.-J. Biokinetics of food additive silica nanoparticles and their interactions with food components. Colloids Surf. B 2017, 150, 384-392. [CrossRef]

13. Jo, M.-R.; Yu, J.; Kim, H.-J.; Song, J.H.; Kim, K.-M.; Oh, J.-M.; Choi, S.-J. Titanium dioxide nanoparticle-biomolecule interactions influence oral absorption. Nanomaterials 2016, 6, 225. [CrossRef]

14. Dobrovolskaia, M.A.; Shurin, M.; Shvedova, A.A. Current understanding of interactions between nanoparticles and the immune system. Toxicol. Appl. Pharmacol. 2016, 299, 78-89. [CrossRef] [PubMed]

15. Parveen, R.; Shamsi, T.N.; Fatima, S. Nanoparticles-protein interaction: Role in protein aggregation and clinical implications. Int. J. Biol. Macromol. 2017, 94, 386-395. [CrossRef] [PubMed]

16. Barbero, F.; Russo, L.; Vitali, M.; Piella, J.; Salvo, I.; Borrajo, M.L.; Busquets-Fité, M.; Grandori, R.; Bastús, N.G.; Casals, E. Formation of the protein corona: The interface between nanoparticles and the immune system. Semin. Immunol. 2017, 34, 52-60. [CrossRef] [PubMed]

17. Yu, J. Effects of Interactions between ZnO Nanoparticles and Biological/Food Matrices on Toxicological Responses. Ph.D. Thesis, Seoul Women's University, Seoul, Korea, 21 August 2020.

18. Coreas, R.; Cao, X.; DeLoid, G.M.; Demokritou, P.; Zhong, W. Lipid and protein corona of food-grade $\mathrm{TiO}_{2}$ nanoparticles in simulated gastrointestinal digestion. NanoImpact 2020, 20, 100272. [CrossRef] [PubMed]

19. Geitner, N.K.; Hendren, C.O.; Cornelis, G.; Kaegi, R.; Lead, J.R.; Lowry, G.V.; Lynch, I.; Nowack, B.; Petersen, E.; Bernhardt, E. Harmonizing across environmental nanomaterial testing media for increased comparability of nanomaterial datasets. Environ. Sci. Nano 2020, 7, 13-36. [CrossRef]

20. Peters, R.; Kramer, E.; Oomen, A.G.; Herrera Rivera, Z.E.; Oegema, G.; Tromp, P.C.; Fokkink, R.; Rietveld, A.; Marvin, H.J.; Weigel, S. Presence of nano-sized silica during in vitro digestion of foods containing silica as a food additive. ACS Nano 2012, 6, 2441-2451. [CrossRef]

21. des Rieux, A.; Ragnarsson, E.G.; Gullberg, E.; Préat, V.; Schneider, Y.-J.; Artursson, P. Transport of nanoparticles across an in vitro model of the human intestinal follicle associated epithelium. Eur. J. Pharm. Sci. 2005, 25, 455-465. [CrossRef]

22. Jo, M.-R.; Bae, S.-H.; Go, M.-R.; Kim, H.-J.; Hwang, Y.-G.; Choi, S.-J. Toxicity and biokinetics of colloidal gold nanoparticles. Nanomaterials 2015, 5, 835-850. [CrossRef]

23. Anders, C.B.; Chess, J.J.; Wingett, D.G.; Punnoose, A. Serum proteins enhance dispersion stability and influence the cytotoxicity and dosimetry of $\mathrm{ZnO}$ nanoparticles in suspension and adherent cancer cell models. Nanoscale Res. Lett. 2015, 10, 448. [CrossRef]

24. Jo, M.-R.; Chung, H.-E.; Kim, H.-J.; Bae, S.-H.; Go, M.-R.; Yu, J.; Choi, S.-J. Effects of zinc oxide nanoparticle dispersants on cytotoxicity and cellular uptake. Mol. Cell. Toxicol. 2016, 12, 281-288. [CrossRef]

25. Elzoghby, A.O.; Elgohary, M.M.; Kamel, N.M. Implications of protein-and peptide-based nanoparticles as potential vehicles for anticancer drugs. Adv. Protein Chem. Struct. Biol. 2015, 98, 169-221.

26. Shukla, R.; Cheryan, M. Zein: The industrial protein from corn. Ind. Crops Prod. 2001, 13, 171-192. [CrossRef]

27. Patil, S.; Sandberg, A.; Heckert, E.; Self, W.; Seal, S. Protein adsorption and cellular uptake of cerium oxide nanoparticles as a function of zeta potential. Biomaterials 2007, 28, 4600-4607. [CrossRef]

28. Fukuzaki, S.; Urano, H.; Nagata, K. Adsorption of bovine serum albumin onto metal oxide surfaces. J. Ferment. Bioeng. 1996, 81, 163-167. [CrossRef]

29. Yu, J.; Kim, H.-J.; Go, M.-R.; Bae, S.-H.; Choi, S.-J. ZnO interactions with biomatrices: Effect of particle size on ZnO-protein corona. Nanomaterials 2017, 7, 377. [CrossRef] [PubMed]

30. Fatehah, M.O.; Aziz, H.A.; Stoll, S. Stability of $\mathrm{ZnO}$ nanoparticles in solution. Influence of $\mathrm{pH}$, dissolution, aggregation and disaggregation effects. J. Colloid Sci. Biotechnol. 2014, 3, 75-84. [CrossRef]

31. Adamcakova-Dodd, A.; Stebounova, L.V.; Kim, J.S.; Vorrink, S.U.; Ault, A.P.; O'Shaughnessy, P.T.; Grassian, V.H.; Thorne, P.S Toxicity assessment of zinc oxide nanoparticles using sub-acute and sub-chronic murine inhalation models. Part. Fibre Toxicol. 2014, 11, 15. [CrossRef]

32. Bian, S.-W.; Mudunkotuwa, I.A.; Rupasinghe, T.; Grassian, V.H. Aggregation and dissolution of $4 \mathrm{~nm} \mathrm{ZnO}$ nanoparticles in aqueous environments: Influence of $\mathrm{pH}$, ionic strength, size, and adsorption of humic acid. Langmuir 2011, 27, 6059-6068. [CrossRef] [PubMed]

33. Voss, L.; Saloga, P.E.; Stock, V.; Böhmert, L.; Braeuning, A.; Thünemann, A.F.; Lampen, A.; Sieg, H. Environmental impact of ZnO nanoparticles evaluated by in vitro simulated digestion. ACS Appl. Nano Mater. 2019, 3, 724-733. [CrossRef]

34. Zhu, M.; Nie, G.; Meng, H.; Xia, T.; Nel, A.; Zhao, Y. Physicochemical properties determine nanomaterial cellular uptake, transport, and fate. Acc. Chem. Res. 2013, 46, 622-631. [CrossRef]

35. Yu, J.; Baek, M.; Chung, H.; Choi, S. Effects of physicochemical properties of zinc oxide nanoparticles on cellular uptake. J. Phys. Conf. Ser. 2011, 304, 012007. [CrossRef]

36. Gamboa, J.M.; Leong, K.W. In vitro and in vivo models for the study of oral delivery of nanoparticles. Adv. Drug Del. Rev. 2013, 65, 800-810. [CrossRef] [PubMed] 
37. Yu, J.; Choi, S.-J. Particle Size and Biological Fate of ZnO Do Not Cause Acute Toxicity, but Affect Toxicokinetics and Gene Expression Profiles in the Rat Livers after Oral Administration. Int. J. Mol. Sci. 2021, 22, 1698. [CrossRef] [PubMed]

38. Ramaiah, S.K. A toxicologist guide to the diagnostic interpretation of hepatic biochemical parameters. Food Chem. Toxicol. 2007, 45, 1551-1557. [CrossRef] [PubMed]

39. Gowda, S.; Desai, P.B.; Kulkarni, S.S.; Hull, V.V.; Math, A.A.; Vernekar, S.N. Markers of renal function tests. N. Am. J. Med. Sci. 2010, 2, 170. [PubMed]

40. McInnes, E.F. Wistar and sprague-dawley rats. In Background Lesions in Laboratory Animals: A Color Atlas, 1st ed.; Mclnnes, E., Mann, P., Eds.; Elsevier: Amsterdam, The Netherlnds, 2012; pp. 17-36.

41. Frazier, K.S.; Seely, J.C.; Hard, G.C.; Betton, G.; Burnett, R.; Nakatsuji, S.; Nishikawa, A.; Durchfeld-Meyer, B.; Bube, A. Proliferative and nonproliferative lesions of the rat and mouse urinary system. Toxicol. Pathol. 2012, 40, 14S-86S. [CrossRef]

42. McInnes, E. Common Spontaneous and Background Lesions in Laboratory Animals. In Pathology for Toxicologists: Principles and Practices of Laboratory Animal Pathology for Study Personnel, 1st ed.; Mclnnes, E., Ed.; Wiley-blackwell: Hoboken, NJ, USA, 2017; pp. 59-71. 